Review

\title{
Buffer Green Patches around Urban Road Network as a Tool for Sustainable Soil Management
}

\author{
Slaveya Petrova ${ }^{1,2, *} \mathbb{C}$, Bogdan Nikolov $^{1}$, Iliana Velcheva ${ }^{1}$, Nikola Angelov ${ }^{1}$, Ekaterina Valcheva ${ }^{2}$, \\ Aneliya Katova ${ }^{3}$, Irena Golubinova ${ }^{3}$ and Plamen Marinov-Serafimov ${ }^{3}$ \\ 1 Department of Ecology and Ecosystem Conservation, Faculty of Biology, University of Plovdiv “Paisii \\ Hilendarski", 24 Tzar Asen Str., 4000 Plovdiv, Bulgaria; nikolov81bg@uni-plovdiv.bg (B.N.); \\ anivel@uni-plovdiv.bg (I.V.); n.angelovv@uni-plovdiv.bg (N.A.) \\ 2 Department of Agroecology and Environmental Protection, Faculty of Plant Protection and Agroecology, \\ Agricultural University, 12 Mendeleev Blvd, 4000 Plovdiv, Bulgaria; e_valcheva@au-plovdiv.bg \\ 3 Agricultural Academy, Institute of Forage Crops, 89 General Vladimir Vazov Str., 5800 Pleven, Bulgaria; \\ aneliya.katova@ifc-pleven.org (A.K.); irena.golubinova@ifc-pleven.org (I.G.); \\ plamen.serafimov@ifc-pleven.org (P.M.-S.) \\ * Correspondence: slaveya_petrova@uni-plovdiv.bg; Tel.: +35-98-9093-3955
}

Citation: Petrova, S.; Nikolov, B.;

Velcheva, I.; Angelov, N.; Valcheva,

E.; Katova, A.; Golubinova, I.;

Marinov-Serafimov, P. Buffer Green

Patches around Urban Road Network

as a Tool for Sustainable Soil

Management. Land 2022, 11, 343.

https://doi.org/10.3390/

land 11030343

Academic Editor: Krish

Jayachandran

Received: 6 February 2022

Accepted: 24 February 2022

Published: 25 February 2022

Publisher's Note: MDPI stays neutral with regard to jurisdictional claims in published maps and institutional affiliations.

Copyright: (C) 2022 by the authors. Licensee MDPI, Basel, Switzerland. This article is an open access article distributed under the terms and conditions of the Creative Commons Attribution (CC BY) license (https:// creativecommons.org/licenses/by/ $4.0 /)$.

\begin{abstract}
Urban areas are facing a range of environmental challenges including air, water and soil pollution as a result of industrial, domestic and traffic emissions. In addition, global climate change is likely to aggravate certain urban problems and disturb the urban ecology by increasing the frequency and severity of extreme weather events. In the context of urbanization growth and the consequent impact on the environment, there is a growing interest in maintaining urban soil quality and functions as they are the medium for green infrastructure development. Furthermore, urban soils are becoming one of the key factors in the delivery of many ecosystem services such as carbon storage, climate regulation, water flow regulation, etc. On the other hand, urban soils are well-known to be a major sink of air pollutants due to the wet and dry atmospheric deposition and recirculation. Soil has the ability to degrade some chemical contaminants but when the levels are high, urban soils could hold on large amounts and pose a risk to human health. A cost-effective technological solution is to use the ability of some plant species to metabolize, accumulate and detoxify heavy metals or other harmful organic or inorganic compounds from the soil layer. The establishment of urban lawns (grass covered surfaces) is a helpful, environmentally friendly, economically sustainable and cost-effective approach to remove contaminants from polluted soils (terrains), which also has some aesthetic benefits. In this paper, an overview of the benefits and limitations of urban lawn construction is presented. The focus is on the perspectives for sustainable management of urban lawns, especially as buffer green patches in the road network surroundings, that can represent strategies to provide ecological and social multifunctionality of urban soils, and thus, increasing their ecosystem services capacity. Specifically, the paper highlights (i) the possibilities for phytoremediation of urban soils, (ii) potential of some perennial grasses and (iii) key issues that should be considered in the planning and design of urban lawns.
\end{abstract}

Keywords: phytoremediation; soil pollution; perennial grasses; green infrastructure; ecosystem services; life quality

\section{Introduction}

The growth of industrial and urban areas is invariably associated with environmental pollution, causing negative changes in the air, water and soil at biological, physical and chemical levels, and is thus revealed to worsen quality of life [1-4]. Anthropogenic activity results in organic and inorganic pollution of urban areas, including with $\mathrm{CO}_{2}, \mathrm{SO}_{2}$, particulate matter (PM), soot, heavy metals, hydrocarbons, aldehydes, etc., that are toxic to humans, animals and the environment as a whole. A permanent level of air pollution 
(even at low doses) significantly affects urban ecosystems (parks, gardens, green areas, etc.), so often they need to be restored and rehabilitated. Furthermore, air pollution is regarded as a factor that contributes to the worsening of human health, so it is of great importance for social well-being [5]. Air pollution is also one of the factors for the deposition of contaminants in the soil, together with waste disposal, pesticides application, road maintenance during winter season, etc. [6] Once in the soil, hazardous elements can pass from one medium to another, as well as in drinking water, living organisms and in the atmosphere (in the form of recirculating dust) [7]. Many studies have shown that when the soil temperature and humidity are disturbed, organic matter and the intensity of self-purification are reduced, but on the other hand, carbon content, compaction and alkalinity of urban soil are increased. Impaired physicochemical properties of soils directly affect their microbial biocenosis composition and structure [5,8].

The World Health Organization reported in 2019 that in megacities and large cities with developed heavy and chemical industries, the level of air, water and soil pollution exceed the maximum allowable values [9]. Environmental problems in settlements are addressed by the use and improvement of green and buffer areas as a means of reducing air and soil pollution due to the increased use of personal and public vehicles as the main sources of pollutants in an urban environment. Over the last decade, much research has been carried out looking for environmentally friendly and safe approaches to reduce the impact of transport on air quality $[4,9,10]$. In many countries, the refusal of personal motor vehicles and the use of alternative transport are encouraged, but the results obtained are often contradictory and environmental problems in settlements are exacerbated.

Historically, urban soils have been ignored for a long time in the scientific research due to the failure to assess their importance to the urban population. According to the UN forecasts, $70 \%$ of the world's population is expected to live in cities in 2050, revealing to the even greater anthropogenic pressure on urban soils [8]. Soil is a major depot for accumulation and infiltration of anthropogenically derived components, which creates significant technical and economic challenges in their removal by conventional methods. At the same time, soil plays a key role in the growth and development of urban vegetation, which in turn contribute to maintaining air and water quality. Urbanization and industrialization of urban areas have a negative impact on the environment and a reduction in soil ecosystem services (mainly due to soil compaction) or a complete absence of soil ecosystem services (due to degradation) are often observed [11]. The trend of increasing the number, role and size of cities is expected to intensify in the coming decades [12], which requires the search for sustainable solutions and management practices in order to compensate for environmental problems caused by urbanization impact on soil quality and functioning [13]. Enhancing green infrastructure is beneficial in mitigating the effects of urban development and biodiversity conservation, as well as in flood management and in the reduction of heat, dust, and air pollution, but requires adequate planning and strategies for their support. This is especially important in terms of urban lawns, as the traditional protection and restoration opportunities of these habitats are limited [14].

In this context, the scope of this paper is to emphasize the relevance of the problem of urban soil pollution and to provide an overview of the benefits and limitations of applying urban lawns as a tool in sustainable soil management. The focus is on the perspectives for construction and the maintenance of buffer green patches in the road network surroundings due to their vulnerability to both traffic pollution and flooding. Approaches, ideas, and techniques for phytoremediation, reported by various authors in terms of accessibility and effectiveness, are discussed. Specifically, the paper highlights some perennial grasses and their potential in phytoremediation of contaminated urban soils-perennial ryegrass (Lolium perenne L.), crested wheatgrass (Agropyron cristatum L.), standard wheatgrass (Agropyron desertorum Fisch.), tall fescue (Festuca arundinacea Schreb), and cocksfoot (Dactylis glomerata L.) This approach is not limited to the simple introduction of vegetation in urban areas, but aims to make the vegetation an active part of urban space design, focusing on human well-being [15]. Therefore, it is needed firstly to identify trends 
across studies which could be developed, generalize and provide different insights into strategies to support the ecological and social multifunctionality of urban soils, and thus increasing their ecosystem service capacity.

\section{Material and Methods}

The initial identification of scientific literature in the field was done by searching for articles using the Scopus, Web of Science and Science Direct platforms in addition to the articles known to the authors. The literature search was carried out in early 2021. The keywords searched were urban soil pollution, traffic pollution, phytoremediation, green infrastructure, urban lawns, and perennial grasses. Some terminology associated with soil processes and functions was also included, such as the ideas of ecosystem services and ecological functions of soils being closely related [16].

Only papers written in the English language were considered. The screening of the outputs was manually performed to first remove duplicates, and then by checking the abstract, methodology and conclusions; only those studies fitting the topic of the paper were selected as eligible, which left 153 papers that were relevant [17]. The three-staged literature review process is presented in Figure 1 following [18].

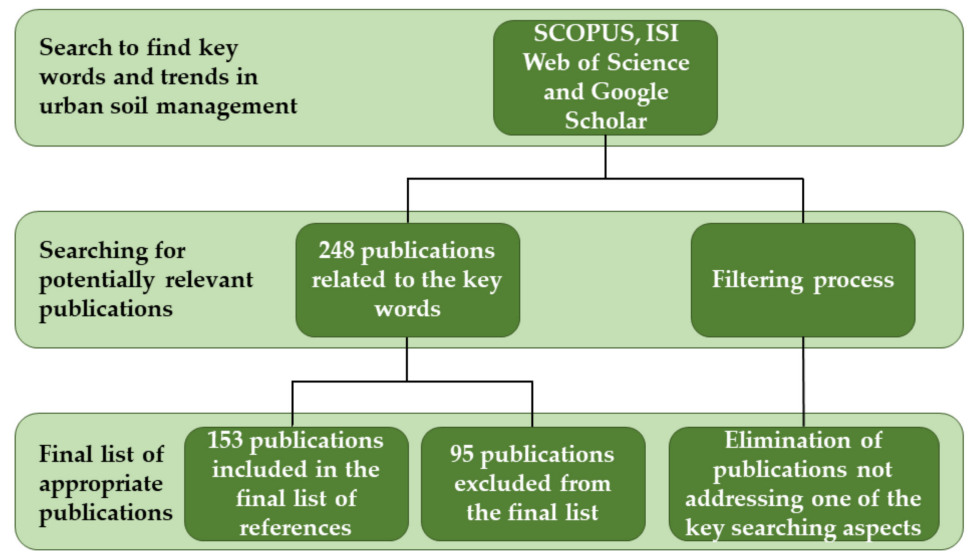

Figure 1. Literature review process.

The analysis is presented in Section 3 (Results) as follows: first, a synthesis of the phytoremediation mechanism is provided (Section 3.1), with a focus on benefits and potential of perennial grasses (Section 3.2) providing examples related to the breeding and selection of varieties with specific features in both urban lawn construction and urban soil remediation. Some technological solutions related to the urban lawn establishment and maintenance are discussed in Section 3.3, providing examples for sowing rate, fertilizing and weed management. Conclusions and future possibilities are given in Section 4 .

\section{Results}

\subsection{Phytoremediation as an Effective Strategy for the Restoration of Soils around the Urban Road Network}

Selected studies by the literature search on urban soil pollution are focused on heavy metals [19-21]; polycyclic aromatic hydrocarbons (PAHs) [22,23]; salts used for road deicing [24] and anthropogenic residues, which further contribute to human health risks. These studies highlight contaminants presented in urban soils and show that reducing public exposure to such contamination is crucial.

Phytoremediation is an effective strategy and is often part of the integrated approach used in environmental restoration programs on contaminated lands [25-29] as it is economically feasible, easy to manage, environmentally friendly, erosion preventing, etc. [30,31]. Phytoremediation involves the use of plants, together with appropriate agronomic practices (liming, application of fertilizers, organic matter, etc.) to remove, immobilize or neutralize pollutants in urban ecosystems [30,32-34]. A number of authors consider the advantages of 
phytoremediation as a cost-effective technological solution using the ability of some plant species to metabolize, accumulate and detoxify heavy metals or other harmful organic or inorganic pollutants accumulated in the soil layer [35-39]. In particular, heavy metals do not decompose in the soil for a long period of time, becoming a long-term environmental threat [40]. Basic heavy metals, such as $\mathrm{Cu}, \mathrm{Fe}, \mathrm{Mn}, \mathrm{Ni}$ and $\mathrm{Zn}$ are part of the physiological and biochemical processes during the life cycle of plants, but can become toxic when their concentration increases [41]. Other heavy metals, such as $\mathrm{Pb}, \mathrm{Cd}$, As and $\mathrm{Hg}$, are highly toxic with no known function in plants and can severely affect various physiological and biochemical processes [42].

It is well-known that phytoremediation is carried out through a number of mechanisms, such as phytotransformation (phytodegradation), phytoextraction, phytostabilization, phytovolatilization and rhizofiltration. Phytoextraction and phytostabilization are the two most popular phytoremediation techniques. Phytoextraction involves the absorption of heavy metals from the soil, their transfer and accumulation into aboveground plant tissues, which are then removed from contaminated soil. The plants used for this process must have a fast growth rate, intensive biomass synthesis and high tolerance to heavy metals. Plants with a well-developed root system are suitable for phytoremediation, capable of performing rhizofiltration, and plants with a well-developed aboveground biomass are preferred for phytoextraction [43].

Plant species with the ability to maintain very low levels of toxic elements in their aboveground part are preferred for phytostabilization or phytoimobilization purposes due to the regulation of absorption and transport mechanisms. Accumulator and hyper accumulator plants are able to store toxic elements, mainly in their aboveground biomass, due to efficient transport from roots to stems (the ratio between stems and roots is greater than one). Such plants are used for efficient phytoextraction and form a significant amount of biomass that can be used after harvest for energy production [44].

Zhang et al. [45] revealed that some perennial grasses accumulate higher amounts of lead $(\mathrm{Pb})$ in their root tissues than in aboveground biomass, with significant genotypic differences between different species. Furthermore, the accumulation of heavy metals in the root system of grass is the largest in the rhizosphere zone of soil. According to the authors, the organic compounds released in the rhizosphere zone contribute to the development of microbial coenoses that accumulate some heavy metals. The accumulative effect, however, depends on the ontogenetic development of the plants in the urban grassland and on the concentration of industrial pollutants in the soil [46]. Other studies found that the formed stable microbial coenoses in the rhizosphere soil zone contribute to the conversion of some toxic hydrocarbons into non-toxic forms, as well as to the degradation of some chemical contaminants in the soil, forming them into substrates for soil microorganisms' development [47-49]. The results obtained in the experimental work of many other authors are quite similar [50-52]. These authors stated also that in addition to the fact that perennial grasses have the ability to accumulate larger amounts of heavy metals in the roots and/or rhizomes, they could represent a vital part of the ecological systems in the urban landscape-for parks construction, roadside buffer green patches establishment, sports fields green cover, etc. Perennial grasses are strongly recommended due to the formed dense vegetation cover after mowing, the high anti-erosion potential, and something more: their aboveground biomass is less flammable after drying when compared to other plants used for decoration and landscaping. The formed grass turf also improves the microclimate, helps to absorb carbon dioxide, increases biodiversity and improves soil fertility in the area. Most of the perennial grasses (especially those with C4 type photosynthesis) have a well expressed tolerance to abiotic and biotic stress with a high potential for growing in a wide range of soil types, climatic and meteorological conditions [53-56].

Based on the above-mentioned, it is obvious that the selection of species and varieties of plants used for phytoremediation is determined by a number of biological characteristics of the species, related to their intensity of growth, accumulation of pollutants in the roots and aboveground biomass, as well as their biological potential for detoxification of 
contaminants [57-59]. When regarding the phytoremediaton of urban soils by the construction of buffer green patches along heavily congested urban roads, these plant species should also be tolerant to various anthropogenic activities and adapt to the unfavorable urban environment.

The use of lawns in urban areas is seen as a product of the modern way of life [60]. Lawns cover a significant part (up to $70-75 \%$ ) of all the open green areas in urban regions. They are built in different parts of the cities-public parks, gardens, golf courses, roadsides, etc. Most people accept lawns in urban areas as "natural" and even as a mandatory element of the urban landscape, without questioning their social, environmental or aesthetic values as well as issues related to their construction, maintenance and use [61].

Grassing of open spaces and along the roadside network with heavy traffic is a practice in many European cities that aims to bring greenery back into urban space and to provide habitats for wild biodiversity. The formed lawns provide many benefits for each urban area, such as reducing the air temperature, forming a permeable surface through which rainwater can penetrate, and so on. Aesthetically green lawns are perceived to be significantly better than the concrete or asphalt cover that forms the urban environment. The landscaping technology around and between the road arteries allows grassing of already existing or new areas, as well as on areas with laid tram rails. Many studies demonstrate that the established urban lawns have a multifaceted positive effect: the green cover, which is close to car traffic, absorbs harmful dust particles from the atmosphere; reduces soil and air temperature; and acts as a natural drainage of rainfall [62-68]. Furthermore, green patches along roads and in open spaces have significantly lower maintenance costs compared to costs if maintaining the same areas but covered by concrete, asphalt and other construction materials. The other benefits of the urban lawns and buffer green patches along the road network are related to the fact that they provide accessibility for snow removal equipment during the winter season; contribute to the drainage of the terrains along the city roads; and reduce noise from the contact between the asphalt road and car tires [62-68]. Landscaping of urban road infrastructure is not a new idea but it it is still based mainly on the aesthetic and physiological criteria for plant composition. There is a need to enhance the role of urban lawns as a tool for restoration and sustainable management of urban soil quality, which could be done by implementing the phytoremediation potential as a criterion in the species-selection process.

\subsection{Perennial Grasses-Benefits and Potential for Phytoremediation of Degraded Urban Soils}

The establishment of urban lawns and green patches is associated by a compliance with a number of technological solutions and requirements that determine their effective use in grassing and formation of natural turf from perennial grasses. Genetic resources of perennial grasses are their populations in natural habitats as well as the adapted ecotypes and varieties in a certain region, maintained by breeding programs and seed production [69]. Using the modern breeding programs, a wide list of varieties with valuable biological features has been created: fast growth rate after mowing, high tolerance to chemical pollutants (toxic substances), significant resistance to abiotic and biotic stress as well as to the impact of economically important diseases and pests [70]. Differences in the intensity of leaf coloration in grass stands allow the formation of various colors and shape panicles which, both with other biological features, are a prerequisite for increasing entomological diversity [71]. The use of perennial grasses in the establishment of urban lawns and buffer zones is an efficient method for sustainable and biological restoration of contaminated and degraded urban soils in a short period of time [72].

Over the last decade, perennial grasses have been preferred by landscape architects when creating decorative compositions in urban landscaping to control soil erosion due to their biological and ecological features [73-76]. Many authors have identified the significant potential of perennial grasses for phytoremediation $[77,78]$. They are characterized by a fast growth rate, a well-developed root system, a large aboveground biomass and a long life cycle. In addition, they show a high tolerance to soil contamination with heavy 
metals [79], so they can accumulate large amounts of heavy metals in both roots and shoots [80-82]. A large number of studies have been conducted on evaluating the processes of uptake, transport, accumulation, and toxicity of trace elements in grasses, assessed for phytoremediation. Undoubtedly, perennial grasses have a tremendous potential to stabilize trace elements in soils, sediments, and wastewater [83-89].

In ecological terms, perennial grasses can be used for phytoremediation, due to their huge biological potential, regenerative capacity after mowing, undemanding fertilization and their ability to grow on poor and unstructured soils, allowing phytomanagement of ecosystems with little investment and minimal maintenance $[25,37,90]$. Thanks to their multi-year life cycle, grasses can be successfully used for phytoremediation, as the aboveground-formed biomass could be easily removed from the grasslands, which determines the continuous phytoextraction of pollutants from the contaminated substrate $[37,50,91]$. The minimum investment in the creation of urban lawns, as well as the long period of use, determines economic profitability, subject to minimum agro technical requirements, measures and approaches [92-96]. From the point of view of the formation of stable ecosystems, perennial grasses are ecologically dominant species, widespread in the world, adapted to grow on rich and well-structured soils, as well as on poor, weak and degraded soils [91,97-100]. The inclusion of perennial grasses in the establishment of urban grasslands is a prerequisite for building sustainable ecosystems by preventing the invasion of weed species [101,102]. Depending on the anthropogenic factor specifics for each urban area, the suitability of specific grass species should be first assessed.

Some experiments have shown that self-cultivation of perennial grasses is less effective when performing phytoremediation of contaminated soils compared to the use of grass-legume mixtures [103-107]. Mixtures of perennial grasses and legumes in different quantitative proportions are widely used in anthropogenic ecosystems, as a means of restoring the structure and quality of the soil and improving the biodiversity and energy flow of substances. With the constantly formed grass cover and a well-structured and developed root system, they protect the soil from water and wind erosion, increase the biological diversity, take part in carbon sequestration, and last but not least, reveal an adequate economic return on the investments made in their creation. Five plant species (sunflower, oat, rye grass, tall fescue, and green gram) were found to be able to survive the mixed contaminated conditions [108].

Ornamental grasses have become increasingly popular in recent years because they are adaptable to a wide range of climatic conditions, including humid and arid areas, with a wider habitat. They require minimal maintenance, have fewer pest problems, and are less demanding on the soil than other ornamental plants [103]. Their many useful features have attracted the attention of landscape architects in landscaping public or private areas, grassing terrains, creating decorative compositions, erosion control, etc. [74] Some of the ornamental grasses have specific panicles and leaf coloration and can attract the wild enthomofauna [71]. On the other hand, ornamental grasses can play a significant role in the phytoremediation of contaminated urban soils.

According to the summary of studies, urban soils are anthropogenically influenced and most often have disturbed properties and functions; however, grasses from the Poaceae family dominate in plant communities and determine the appearance of the vegetation in the free undeveloped spaces in the settlements, thanks to their high ecological plasticity and stability [37,109-113]. Over the last 20-25 years, European park science and practice has paid considerable attention to the creation and use of public green spaces. Since the 1990s, there has been a trend to replace the demanding exotic species with sustainable plantations from native species [114,115]. In a number of industrial and metropolitan cities, landscape designers develop projects of urban compositions in park areas, using many perennial grasses (Lolium perenne L., Agropyron desertorum (Fisch. ex Link) Schult, etc.) for ornamental purposes [115-118].

The genus Lolium from the Poaceae family is one of the most famous genera of grasses used in the world for fodder and ornamental purposes. Perennial ryegrass 
(Lolium perenne L.) is a widespread species, with good rooting, rapid initial growth, biomass productivity, tolerance to trampling, mowing and grazing, with high nutritional value for ruminants $[116,119,120]$. Referred to as the so-called phytoaccumulators, it can accumulate up to $1-2 \%$ potentially toxic elements (PTE) [121]. It is classified as a tolerant plant to air dust and is used for grassing polluted soils in urban environments, as well as in open spaces and parks. Perennial ryegrass has the ability to reduce soil erosion, improve microbial activity, soil fertility and carbon storage [122]. It is recommended to be successfully used for biological remediation of significantly contaminated soils with heavy metals, although the formed aboveground biomass from the culture growing on contaminated soils is often lower [123-127]. Italian ryegrass (Lolium multiflorum) can grow successfully in soil with increased content of cadmium $(\mathrm{Cd})$ and lead $(\mathrm{Pb})$, with no symptoms of visual phytotoxicity in culture [121,128,129]. Similar results are reported by Li et al., which have found that perennial ryegrass develops without visible phytotoxic symptoms, forms a dense grass cover on sediment substrate, although the yield of the aboveground biomass decreases from 2 to $43 \%$, and in the presence of heavy metals $\mathrm{Cu}, \mathrm{Zn}, \mathrm{Ni}, \mathrm{Cd}$ and $\mathrm{Pb}$ in soil profile, the reduction of aboveground biomass is in the range of 6 to $44 \%$ [130]. Lolium perenne L. has been recently described as a suitable plant to restore metallurgical sites [123,131,132]. The authors confirmed that this plant species seems to accumulate $\mathrm{Cd}$ and $\mathrm{Zn}$ from soils as previously reported in urban areas [133-135]. The possibility to use Italian ryegrass in the remediation of aqueous and soil solutions polluted with terbuthylazine-a herbicide belonging to the triazines class and widely used in agriculture for crop protection-was also reported by Mimmo et al. [136] Phytoremediation ability of perennial ryegrass assisted by Pseudomonas to remove DDTs has been also documented and it was found that the plants may enhance the rhizosphere environment for microorganisms and promote the bioremediation of pollutants [137].

Another large genus of the Poaceae family is the genus Festuca with over 600 species described. Festuca spp. are distributed mostly in the temperate zones of both hemispheres, but more abundantly in the Northern Hemisphere [138]. Fescue grass is an important component of natural, permanent and artificially created lawns and has an important role in landscape protection against climate change. The group of fescue with broad leaves includes meadow fescue (F. pratensis Huds.) and tall fescue (F. arundinacea Schreb.). The narrow-leaved fescue group (with fine leaves) includes red fescue (F. rubra L.) and sheep ovine (F. ovina L.). Narrow-leaved species have minimal water loss during plant respiration, and are characterized by intensive growth after mowing or trampling. Their tolerance to soil acidity ( $\mathrm{pH}=5.5-6.5)$, climatic conditions (severe drought) and shading makes them commercially and economically valuable for grassing in urban areas and for decorative purposes [139-142]. Red fescue (Festuca rubra L.) has been successfully used to prevent erosion and stabilize slopes, canals and river banks [143]. In their experimental work, Begonia et al. found that the species also has a high potential for phytoextraction of lead $(\mathrm{Pb})$, developing on heavily lead-contaminated soils without any visible phytotoxic symptoms and without reducing the formed aboveground biomass from the crop [144]. Festuca arundinacea 'Rahela', may absorb a relatively high amount of heavy metal ions from the soil, without significant reduction of biomass yield, what is expected in the case of bioremediation practices. So, this cultivar could be regarded as a potential candidate for the phytoextraction of Cd-contaminated soil [145].

The genetic resources of perennial grasses are populations in natural habitats or region-adapted ecotypes and varieties, maintained by seed production [69]. The genetic improvement of cereal grasses is the subject of research in various breeding programs. Varieties with high potential for biomass production have been created using modern technologies and selection schemes. The creation of varieties with high growth potential after mowing, resistance to stressors (toxic substances, drought and low temperatures), major diseases and pests should also be the subject of such programs. It is also necessary to create varieties with potential in warmer and colder regions, which increases the possibility of commercialization compared to the market opportunities of such technologies [70]. 
As an example, some achievements of the Institute of Forage Crops (IFC), Pleven, Bulgaria, in the selection of perennial grasses with potential for urban lawns construction and phytoremediation of urban soils are presented. This institute is a part of the Bulgarian Agricultural Academy and performs long-term breeding and improvement work with perennial grasses. Five new varieties with complex qualities are certified and entered in the Official variety list of the Republic of Bulgaria, incl. Perennial ryegrass, Crested wheatgrass and Standard wheatgrass.

Cocksfoot (Dactylis glomerata L.) Variety Dabrava (Figure 2)-The plants have an upright habit (hay type). It belongs to the group of medium-late varieties with great vitality and longevity of use. It is resistant to abiotic stress under the influence of drought and low temperatures, tolerant to leaf and stem rust with a prolonged period of use of 5 years or more [146].

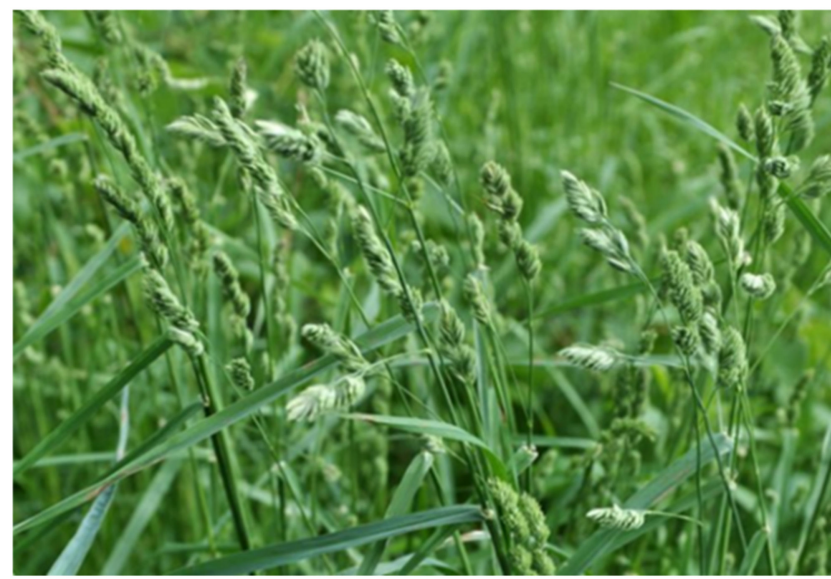

Figure 2. Cocksfoot (Dactylis glomerata L.) Variety Dabrava. Author's photos of Prof. A. Katova.

Tall fescue (Festuca arundinacea Schreb) Variety Albena (Figure 3)-The plants have a semi-upright habit. The generative shoots are relatively thin with 4-5 internodes, resistant to lodging. The variety is drought-tolerant, cold and frost resistant, and with high tolerance to leaf and stem rust. Plants are characterized by great vitality and longevity (over 9-10 years) [146].

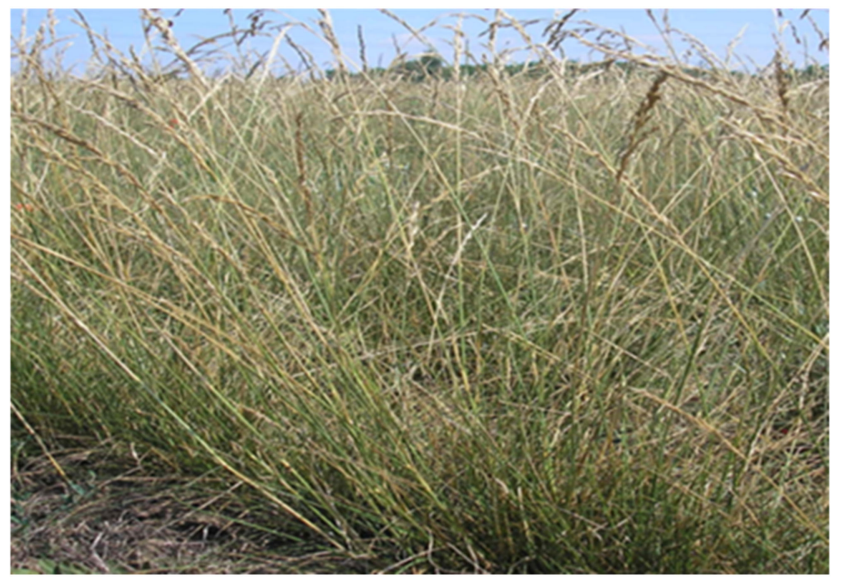

Figure 3. Tall fescue (Festuca arundinacea Schreb) Variety Albena. Author's photos of Prof. A. Katova.

Three varieties of Perennial ryegrass (Lolium perenne L.) are created in recent years, both grow very early in spring when the soil warms up to $3-4{ }^{\circ} \mathrm{C}$ and continue their vegetation until the first frosts. They are tolerant to frequent mowing, have a greater durability, winter hardiness and tolerance to drought and high summer temperatures. 
IFC Harmoniya (Figure 4) is a diploid variety. The plants have a well-developed bearded root system, intensive tillering, with a semi-upright to upright habitus relatively resistant to lodging. The leaves are linearly flat or slightly curved, dark green, smooth and shiny on the underside [147].

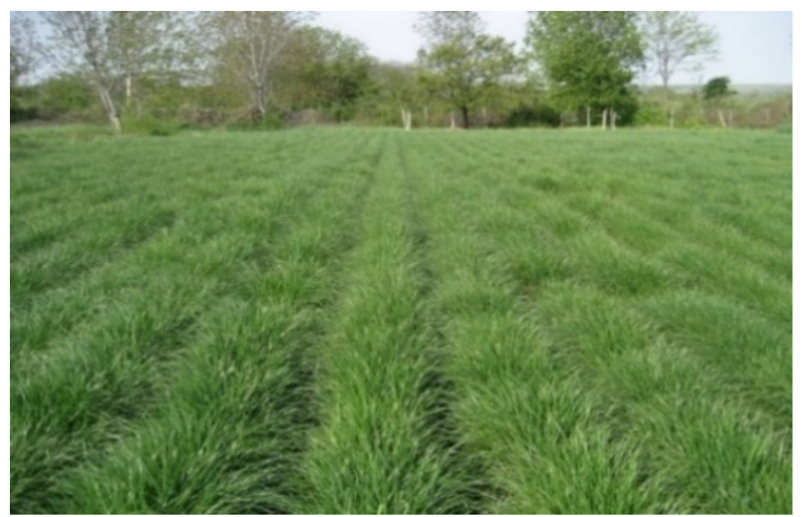

Figure 4. Perennial ryegrass (Lolium perenne L.) Variety IFC Harmoniya. Author's photos of Prof. A. Katova.

Tetrany (Figure 5) is a tetraploid variety of perennial ryegrass. It is early- to mediumearly, ecologically stable (winter hardy and drought tolerant), highly productive and long-lasting. The plants have a well-developed bearded root system, intensive tillering. They form numerous and well-leaved generative and vegetative shoots. The generative shoots are $2.8 \mathrm{~mm}$ thick stems, smooth, and relatively resistant to lodging, with 4-5 leaves. The leaves are linearly flat or slightly curved, very dark green, smooth and shiny on the underside. The variety is multifunctional, suitable for grazing, hay-grazing and ornamental use, alone or in mixtures with red fescue for decorative and sports-technical stands, with a high percentage of soil cover [148].

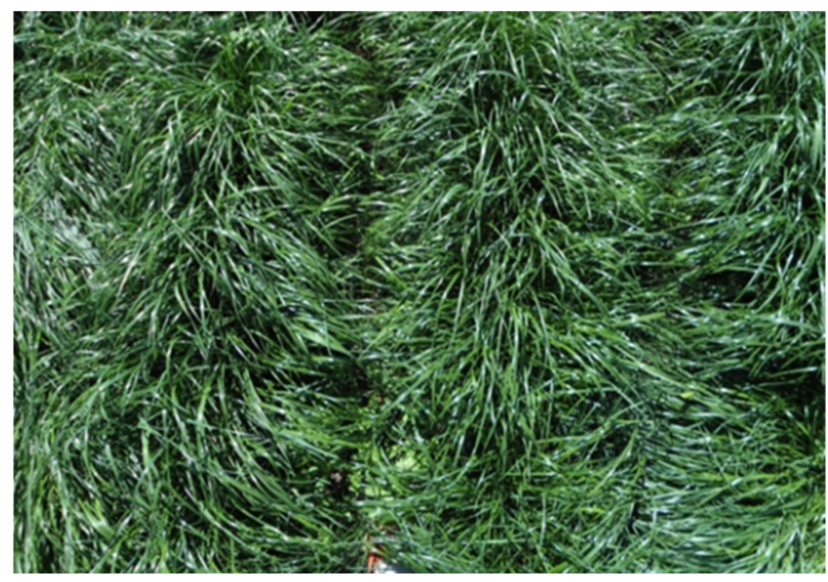

Figure 5. Perennial ryegrass (Lolium perenne L.) Variety Tetrany. Author's photos of Prof. A. Katova.

Tetramis (Figure 6) is a tetraploid variety, very early, highly productive, ecologically stable (winter-hardy and drought-tolerant) and long-lasting. It forms well-leaved generative and vegetative shoots, resistant to lodging, with 4-5 leaves. The foliage of the plants is $35-43 \%$. The leaves are linearly flat or slightly curved, light green, smooth and shiny on the underside. It is suitable for creating meadows and pastures, urban landscaping, etc. [149]. 


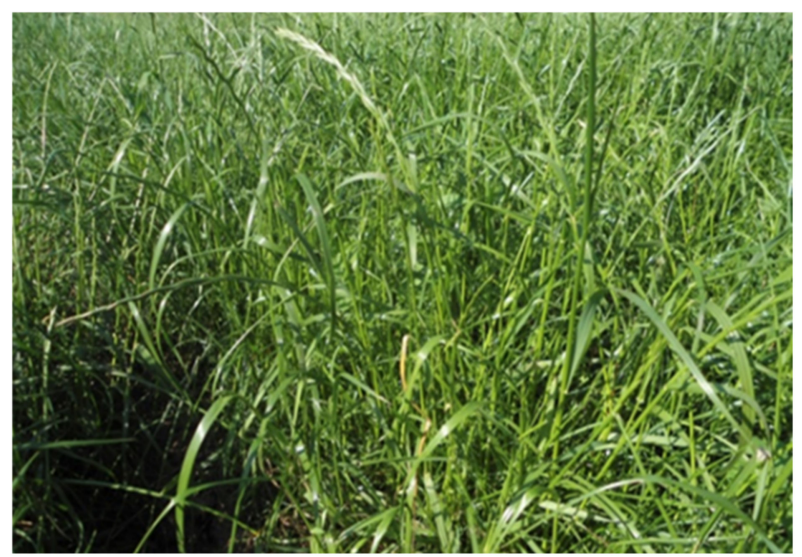

Figure 6. Perennial ryegrass (Lolium perenne L.) Variety Tetramis. Author's photos of Prof. A. Katova.

Two varieties of Agropyron sp. have also been created in recent years, both beginning vegetation in early spring when the soil warms up to $3-4{ }^{\circ} \mathrm{C}$ and continuying until the first frosts. They are characterized as having a very long durability over 10 years, a high winter hardiness and drought resistance, resistance to leaf diseases and tolerance to high summer temperatures.

Crested wheatgrass (Agropyron cristatum L.) Variety Svejina (Figure 7)—The plants are xeromesophytic with a deeply developed root system, mainly located in the soil layer up to $1 \mathrm{~m}$ and reaching a maximum depth of $2.4 \mathrm{~m}$, with an upright habit. It forms numerous and well-leaved generative and vegetative shoots. The generative shoots are $1.8-2.0 \mathrm{~mm}$ thick, smooth, and resistant to lodging, with 5-6 leaves. The leaves are linearly flat, medium in size, slightly curved, are light to blue-green, smooth in length $(17-18 \mathrm{~cm})$ and width $(4-5 \mathrm{~mm})$, and the lowest ones are sometimes hairy. It is suitable for creating anti-erosion grass areas and maintaining the landscape [150].

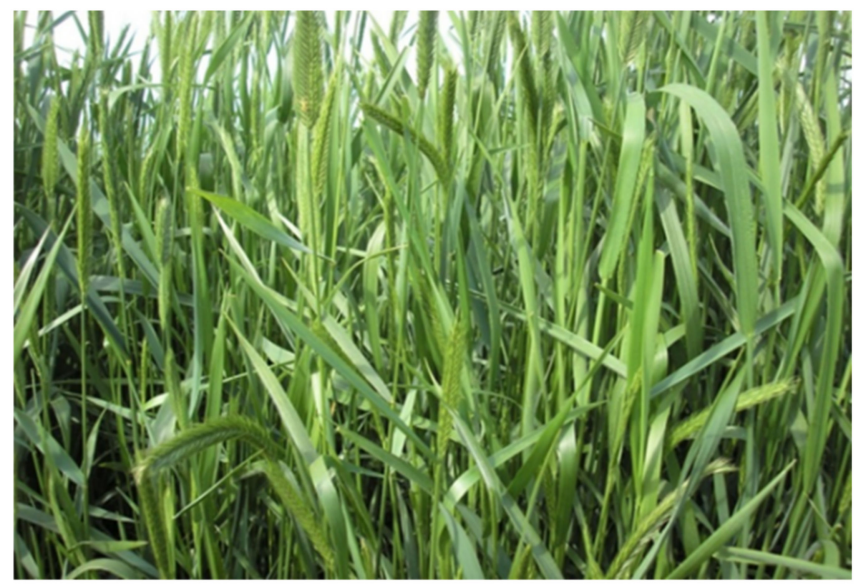

Figure 7. Crested wheatgrass (Agropyron cristatum L.) Variety Svejina. Author's photos of Prof. A. Katova.

Standard wheatgrass (Agropyron desertorum Fisch.) Variety Morava (Figure 8)-The plants are xerophytic with a deeply developed root system, mainly located in the layer $1 \mathrm{~m}$ and reaching a maximum depth of $2.4 \mathrm{~m}$, with an upright habit. Forms well-leaved generative and vegetative shoots resistant to lodging, with 5-6 leaves. The leaves are linearly flat or slightly curved, grey-green, smooth, and the lowest ones are sometimes hairy. The length and width of the leaf are $21-23 \mathrm{~cm}$ and $5-7 \mathrm{~mm}$, respectively. It is suitable for creating anti-erosion grasses and for maintaining the landscape [151]. 


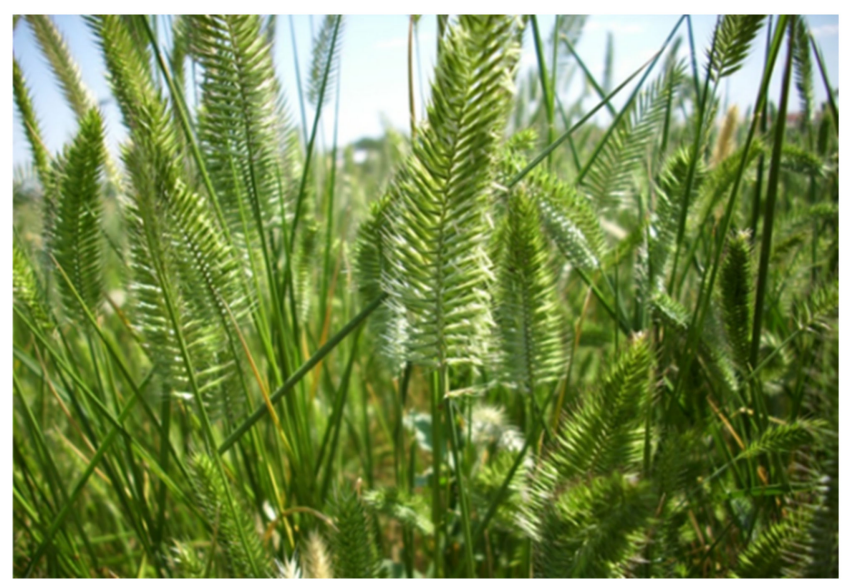

Figure 8. Standard wheatgrass (Agropyron desertorum Fisch.) Variety Morava. Author's photos of Prof. A. Katova.

\subsection{Technological Solutions for Urban Lawns Establishment and Integrated Weed Management}

Building grass stands with perennial grasses in an urban environment is a responsible process based on many years of research [152]. The formation of urban lawns depends on many factors: climatic and meteorological features of the region; soil characteristics; natural vegetation in the region (type and degree of weed infestation); the species composition of the local biodiversity and the needs for its protection and restoration [153]. Grassing and landscaping in urban conditions for decorative purposes is applied not only when creating new areas, but also when restoring the existing ones [154]. The construction of lawns is added as a counteraction to erosion, salinization, acidification and/or soil pollution, climate change and so on [155].

General recommendations on the best sowing rates for ryegrass pastures have remained unchanged for decades. The recommended sowing rates for new perennial ryegrass stands are around $20 \mathrm{~kg}$ of seeds per hectare $(\mathrm{kg}$ seeds/ha) for diploid cultivars and $28 \mathrm{~kg}$ seeds/ha for tetraploid cultivars (due to the tetraploid's larger seed size). Ryegrasses and fescues typically have about $400-500$ seeds per gram, which when applied at $20 \mathrm{~g} / \mathrm{m}^{2}$ equates to $8000-10,000$ seeds per $\mathrm{m}^{2}$. At $35 \mathrm{~g} / \mathrm{m}^{2}$, this equates to $14,000-17,500$ seeds per $\mathrm{m}^{2}$, which is usually adequate for repairing or restoring areas where existing plants are already in situ. Decades of research have shown little advantage of moving away from those standard rates. However, some authors suggest that the sowing rates should be higher to ensure a good establishment, or lower to prevent seedling competition that compromises their ability to survive in the first summer after sowing [156]. There is a study revealing that the increasing seeding rates of perennial ryegrass at 0,195 , 390 , or $585 \mathrm{~kg} \mathrm{ha}^{-1}$ could reduce the total sediment loading, with up to $48 \%, 67 \%$ and $86 \%$ (respectively) of sediment eroded from bare soil over the 42-day establishment period [157].

Many urban lawns and parks receive frequent inputs of fertilizers, herbicides and irrigation depending on the local climate $[158,159]$. This is costly and at odds with reduced funding for managing public spaces in many developed regions [160]. Therefore, alternative landscape materials are being promoted in urban areas, which require less nitrogen fertilizer inputs than traditional turf grass vegetation. However, when planting perennial grasses, fertilization and watering are one of the most important factors for the formation of dense grass cover. According to Carrico et al. [161] and Martini and Nelson [162], both actions are obligatory due to the reduced type of composition in the grassy areas built in the settlements.

In the summary studies of Fuentes [163] and Nielson and Smith [164], it is pointed out that the grassland formation in urban areas requires more intensive lawn care regimes with the application of fertilizers associated with intensive summer irrigation and more frequent mowing in monoculture grass areas. It was found that for the optimal development, the perennial grasses in urban lawns need relatively larger amounts of nitrogen, which is a 
major limiting factor for the formation of dense grass cover with good aesthetic qualities, associated also with the habit of aboveground biomass and the intensity of plant coloring in green [165].

Nitrogen fertilizers are imported depending on the type of development of perennial grasses: "winter" or "winter-spring". For species with winter-spring type development, nitrogen fertilizers are imported as follows: $50-70 \mathrm{~kg} / \mathrm{ha}$ in spring and $50-80 \mathrm{~kg} / \mathrm{ha}$ in autumn. For species with a "winter" type of development, $50-70 \mathrm{~kg} / \mathrm{ha}$ of nitrogen fertilizer is applied in the autumn in order to stimulate the intensity of wrinkles and the formation of shortened vegetative shoots, on which the density of grass next year largely depends and $50-80 \mathrm{~kg} / \mathrm{ha}$ is applied in the spring. In their studies, Brum et al. [166] found that the optimal rate of nitrogen fertilization can be up to $60 \mathrm{~kg} \mathrm{~N} /$ ha per year if the mowing frequency is increased, as nitrogen fertilization increases the productivity of aboveground grassland biomass.

Phosphorus, another macronutrient in plants, is needed for energy reactions and is also often imported as a fertilizer. Relatively few studies have studied the impact of fertilization in urban areas [167] compared to the natural meadows and pastures one [168]. According to the summarized studies for pedoclimatic conditions of Bulgaria, it is recommended to apply $280-300 \mathrm{~kg} / \mathrm{ha}$ of active ingredients $\mathrm{P}_{2} \mathrm{O}_{5}$ and $120-150 \mathrm{~kg} / \mathrm{ha}$ of active ingredients $\mathrm{K}_{2} \mathrm{O}$ in phosphorus-poor and moderately potassium-rich soils [169].

Carey et al. [165] have found that the combined application of fertilizers is a better approach to achieving healthy grass and minimizing the potential for nutrient loss. Their study also documents that the application of $\mathrm{N}$ and $\mathrm{P}$ fertilizers is most appropriate in the phase of intensive growth of cereal grasses, when there is the greatest capacity for fertilizer use in urban areas. Fertilization carried out outside the period of active growth in conditions of cold and drought is a prerequisite for nutrient loss [170]. However, the application of nitrogen fertilizers that exceed plant needs and soil capacity can have an undesirable effect on grasslands, while the potential for high $\mathrm{N}$ losses in response to overfertilization may increase with grass ageing [171]. Excessive amounts of nitrogen in lawns can enter into groundwater such as ammonium $\left(\mathrm{NH}^{4+}\right)$ and nitrate $\mathrm{NO}^{3-}$ by leaching [172], threatening public health [173] or entering the atmosphere by evaporation of ammonia $\left(\mathrm{NH}_{3}\right)$ and emissions of nitric oxide $\left(\mathrm{N}_{2} \mathrm{O}\right)$ and nitrogen monoxide $(\mathrm{NO})$ during nitrification and denitrification [174]. Due to the economic and environmental problems caused by the use of nitrogen fertilizers in urban environments, many authors recommend that nitrogen fertilization should not be carried out as a practice for urban lawns management.

Weed control is also one of the basic prerequisites for obtaining a dense grass cover on the soil surface. Weed infestation is a major problem affecting lawns and is often the result of urban low-level grass maintenance [175]. According to Streibig [176] and Qiang [177], the composition of weed species in a cultivated area is usually highly dependent on the geographical region and the cultivated plant species. In their summary studies, Zhang et al. [178] found that the weed community within urban lawns encompass more than 37 species of weed belonging to 14 families. Perennial weeds represent $45.9 \%$ of the total weed community, while annual or biennial weeds account for $54.1 \%$ and the percentage of deciduous weeds is $94.6 \%$. According to the authors, the dominant weed species (integration of relative weed height and relative cover) and relative abundance (integration of relative weed density, frequency and uniformity) in spring for Asian conditions are Taraxacum mongolicum Hand.-Mazz., Inula japonica Thunb., Hemistepta lyrata Bge., Trigonotis pedunclaris (Trev.) Benth., Calystegia hederacea Wall., Lepidium apetalum Willd., Plantago asiatica L., Cirsium segetum Bge. and Ixeanceris sonchifolia. Ixeris polycephala Cass. and T. mongolicum Hand.-Mazz. They are directly related to factors such as soil nutritional conditions (N, P and K content), soil physical properties (density and clay content), soil moisture, soil temperature, $\mathrm{pH}$ and human anthropogenic activity.

According to the summarized studies of Andreeva-Fetvadzhieva [179] and Bogdanov et al. [180], when perennial rhizome weeds such as Sorghum halepense (L.) Pers., Agropyron repens (L.) P. Beauv., Cynodon dactylon (L.) Pers. or the emergence of root weeds 
such as Cirsium arvense (L.) Scop. and Convolvulus arvensis L. predominate in uncultivated areas and in free urban spaces, then weed control should be done before sowing. According to studies by Peerzada [181], Harlan [182] and Sheley [183], perennial weeds are an economically and agronomically significant factor in urban lawns, urban parks, and urban horticulture and cause up to $88 \%$ of losses.

The successful solution of the problem of available weeds is carried out through a set of measures including: mechanical weeds control, selection of appropriate species and varieties, application of highly effective synthetic herbicides and biological products for weed control. The practices of weed management and control through the use of herbicides are potentially associated with negative impacts on the urban environment [184,185]. The conventional herbicides used can have a phytotoxic effect on nearby areas, as well as migrating into ground water.

The present stage of weed control in urban lawns requires a phytocenological approach with a dosed anthropogenic impact, with mechanical and physical methods to regulate the degree of weed infestation and the application of environmentally friendly methods of weed control depending on their species diversity [186]. When weeds infestation in the green areas is dominated by species with perennial rhizomes, such as Johnson grass (Sorghum halepense (L.) Pers.), Couch grass (Agropyron repens (L.) P. Beauv.), Bermuda grass (Cynodon dactylon (L.) Pers.), or by root-sprouting weeds as Canada thistle (Cirsium arvense (L.) Scop.) and Bindweed (Convolvulus arvensis L.), then the weed control should be made even before the establishment of the grass plots.

The choice of herbicide depends on the type of perennial grasses, the composition of weeds, the degree of weed infestation and the distance from the settlements. The optimal growth stage for weed treatment is "inflorescence emergence, heading" of cereals and "flowering" of deciduous weeds in the year before the establishment of the urban lawns. It is recommended to use the lower-than listed rates for herbicide application.

Weed control in the year of grass establishment is of particular importance, as perennial grasses are characterized by a very slow initial rate of growth, development and biomass synthesis. Dimitrova [187] and Damyanova [188] revealed that the best results are obtained when the herbicides are applied in the initial stages of the development of cereal grasses (from the second to third leaf of tillering). In the first years after the grass area establishment, the herbaceous plants have a higher competitiveness to weeds; however, the application of herbicides with a high selectivity should be carried out in the growth stage "stem elongation". A wide range of synthetic herbicides based on active substances pinoxaden, metsulfuron methyl, dicamba, tritosulfuron, chlorsulfuron and others can be applied, and significant differences in their selectivity when used in urban lawns with different types of perennial grasses have been reported [189-191]. The use of herbicides for vegetative application at more advanced stage of growth and development of perennial weeds or on grasses under stress conditions (drought, over-moisture, lack of nutrients, etc.) may reduce the effectiveness of products and/or cause a severe phytotoxic effect on urban lawns, which can lead to disruption of the soil cover formed by grasses [187].

The most effective approach is the integrated one, which combines a set of different measures, methods and tools to control weeds combined with the application of highly effective synthetic herbicides and biological products to weed control [192,193]. Direct weed control includes:

(1) Mechanical and physical methods for the destruction of the weeds, their seeds and aboveground organs for vegetative propagation, through differentiated tillage, depletion, exposure to temperatures (low or high) of the rhizomes and organs for vegetative propagation. Rhizome and root-weed weeds are highly invasive, easily propagated in a vegetative way and spread quickly, so in areas of heavy weed infestation with them should not be used tillage equipment with cutting organs (cutters, disc tools);

(2) Chemical weed control with pesticides have advantages over mechanical and physical methods, but cannot always be applied in urban areas. The use of environmentally friendly herbicide agents is preferable. Chemical weed control in urban lawns is 
characterized as follows: chemical agents are applied in small doses of the active ingredients per hectare; application should be carried out quickly and easily in a short time; weeds are mortified in a short time after treatment (from 7 to 21 days); both the above-ground biomass is destroyed and the root system and/or the rhizomes are partially suppressed; the method allows the process to be mechanized, which makes it possible to reduce the financial costs from 50 to $80 \%$. In this sense, it is necessary to carry out an effective and sustainable weed management process by integrating the various control methods (i.e., cultural, mechanical and chemical) in a harmonious way without damaging the whole ecosystem. In this way, intensive mechanization and the use of herbicides should be avoided [194]. However, complete removal of actual (sprouted plants) and potential (seed bank) weeds is unattainable [195].

A high effect is achieved by combining differentiated tillage and applications of total herbicides for foliar application in the previous year of grassland creation if possible and the event does not pose risks to the human health and the migration of residual quantities in the soil profile. Synthetic herbicides are not recommended for use on sloping terrains, near residential buildings and on unstructured and sandy soils. Overall, it is estimated that only about $0.1 \%$ of pesticides reach the target plants, and the rest of $99.9 \%$ pollute the environment [196]. Repeated use of sustainable pesticides is a prerequisite for contaminating ecosystem components. Pesticides entering the food chain have been shown to bio accumulate at a higher trophical level.

Recently, several acute and chronic human diseases have been associated with exposure to the pesticides applied near settlements and/or in urban environment [197]. Despite the conflicting views on the impact of herbicides on ecosystems, weed infestation can adversely affect natural areas, urban parks, urban landscape and infrastructure through:

- Anticipating native plants or landscape species for resources such as water, light, space and nutrients, potentially reducing their survival.

- Causing inconvenience and potential danger (if they are prickly) for people, reducing the quality of the grass cover of sports grounds/playgrounds, etc.

- $\quad$ Reduction/replacement of natural habitats and food sources for native animals and insects, leading to increased pressure on local populations and potential extinction of local species.

- Damage or displacement of infrastructure with invasive species with well-developed root systems.

Weed control is an essential and necessary measure for maintaining the aesthetic and entertainment values of urban parks and other landscapes, protecting the ecological values of urban green areas [198].

In urban areas, only the best environmentally friendly techniques and commercial products should be used to weed management in parks, ornamental gardens, roadside vegetation, etc. Although scientific studies on the negative impact of environmentally friendly products for weed control is limited and their use is strongly encouraged to reduce the use of synthetic herbicides. Most environmentally friendly weed control products are developed on the basis of organic oils (clove oil, eugenol and d-citric), soaps, acetic acid, nitric acid, citric acid, etc., which destroy the leaf cuticle and cause cell death resulting in necrosis and lesions on plant leaves similar to burning [192,193].

Commercial fatty acid-synthesized products have a similar action to non-selective contact herbicides, which effectively control annual deciduous and some cereal weeds in the early stages of their ontogenetic development $[199,200]$. According to Coleman and Penner [201], pelargonic acid (nonanoic acid) is a naturally occurring fatty acid in geranium oil (Pelargonium spp. L'Her.) Pelargonic acid can be used as a desiccant in a number of crops before harvest [202]. Other studies have shown that pelargonic acid (nonanoic acid) can be used to control weeds in grassy roadside strips in urban areas [199,201,203-205], although there are concerns among members of the European Commission as no methodologies have been developed for the registration of natural products due to a lack of appropriate toxicological data on their commercial use [206]. Essential oils and their biologically 
active compounds have been shown not to be genotoxic or harmful to human health [207]. According to the performed toxicity tests by European Food Safety Authority, the pelargonic acid has no toxic effect on birds, fish and honey bees [208].

It has been found that organic products with an herbicidal effect destroy only the aboveground biomass of plants and do not provide long-term control of weeds with a well-developed root system or underground reproductive organs, such as rhizomes, tubers or bulbs [209-211]. Despite some of the shortcomings in the last decade, they have been widely used in urban areas [203]. An advantage of environmentally friendly weed control agents is the rapid initial effect they have, similar to contact herbicides, but for good efficacy against weeds they require a larger contact area with the aboveground weed biomass. It is especially important to carry out treatment at the points of growth, otherwise the weed species will grow again.

\section{Conclusions}

The present paper, starting from a general analysis of urban soil pollution by traffic emissions, focuses on the establishment of buffer green patches around urban road networks as a promising tool for soil restauration. Although the dimensions and shapes of urban lawns could vary significantly in different settlements, their integration in urban areas is important for amplifying the benefits that these green technological solutions can bring to the enhancing urban quality of life.

Such strategies are discussed from a new point of view that takes into consideration not only the simple introduction of vegetation into the cities, but looks at the vegetation as an active part of the design of urban space to maximize its benefits and to minimize the negative anthropogenic load. Grass-covered urban areas are a low-cost, environmentally friendly and biodiversity-enhancing tool for sustainable urban soil management.

This review is not exhaustive and a further analysis is foreseen, but it is expected that this paper opens to a new vision for urban planning and development as well as for enhancing the values of ecosystem services in urban areas.

Author Contributions: Conceptualization, I.G., P.M.-S. and S.P.; methodology, A.K., I.G. and P.M.-S.; validation, A.K., P.M.-S., I.G., E.V., I.V., N.A., B.N. and S.P.; formal analysis, S.P. and P.M.-S.; investigation, A.K., P.M.-S. and I.G.; resources, A.K. and I.G.; data curation, E.V., N.A. and B.N.; writing — original draft preparation, P.M.-S. and S.P.; writing-review and editing, S.P.; visualization, S.P. and P.M.-S.; supervision, I.V. All authors have read and agreed to the published version of the manuscript.

Funding: This research was funded by Bulgarian National Science Fund, grant number KP 06 OPR $03 / 12$.

Institutional Review Board Statement: Not applicable.

Informed Consent Statement: Not applicable.

Data Availability Statement: Not applicable.

Conflicts of Interest: The authors declare no conflict of interest.

\section{References}

1. Vardoulakis, S.; Dear, K.; Wilkinson, P. Challenges and Opportunities for Urban Environmental Health and Sustainability: The HEALTHY-POLIS initiative. Env. Health 2016, 15, S30. [CrossRef]

2. Vardoulakis, S.; Kinney, P. Grand Challenges in Sustainable Cities and Health. Front. Sustain. Cities 2019, 1, 7. [CrossRef]

3. Kulińska, E.; Dendera-Gruszka, M. Green cities-Problems and solutions in Turkey. Transp. Res. Procedia $2019,39,242-251$. [CrossRef]

4. World Health Organization. Healthy Environments for Healthier Populations: Why Do They Matter, and What Can We Do? 2019. Available online: https://www.who.int/publications/i/item/WHO-CED-PHE-DO-19.01 (accessed on 20 December 2021).

5. Sager, L. Estimating the effect of air pollution on road safety using atmospheric temperature inversions. J. Environ. Econ. Manag. 2019, 98, 102250. [CrossRef] 
6. Grebenshchikova, E.; Shelkovkina, N.; Gorbacheva, N. Biological remediation of roadside areas. In Proceedings of the E3S Web of Conferences, Ecological and Biological Well-Being of Flora and Fauna (EBWFF-2020), Blagoveshchensk, Russia, 23-24 September 2020; Volume 203, p. 05008. [CrossRef]

7. Mamat, Z.; Yimit, H.; Ji, R.Z.A.; Eziz, M. Source identification and hazardous risk delineation of heavy metal contamination in Yanqi basin, northwest China. Sci. Total Environ. 2014, 493, 1098-1111. [CrossRef]

8. Milošević, D.; Nagy, I.; Stojanović, V. Soils in the cities: State, problems and remediation tehniques. Res. Rev. Dep. Geogr. Tour. Hotel. Manag. 2014, 43, 1-16.

9. Gwilliam, K.; Kojima, M.; Johnson, T. Reducing Air Pollution from Urban Transport. The World Bank. 2004. Available online: https:/ / esmap.org/sites/default/files/esmap-files/urban\%20pollution\%20entire\%20report.pdf (accessed on 20 December 2021).

10. Titos, G.; Lyamani, H.; Drinovec, L.; Olmo, F.J.; Močnik, G.; Alados-Arboledas, L. Evaluation of the impact of transportation changes on air quality. Atmos. Environ. 2015, 114, 19-31. [CrossRef]

11. Kumar, K.; Hundal, L.S. Soil in the City: Sustainably Improving Urban Soils. J. Environ. Qual. 2016, 45, 2-8. [CrossRef]

12. Oertli, B.; Parris, K.M. Review: Toward management of urban ponds for freshwater biodiversity. Ecosphere 2019, 10, e02810. [CrossRef]

13. Deeb, M.; Groffman, P.M.; Blouin, M.; Egendor, S.P.; Vergnes, A.; Vasenev, V.; Cao, D.L.; Walsh, D.T.; Séré, M.G. Using constructed soils for green infrastructure-Challenges and limitations. Soil 2020, 6, 413-434. [CrossRef]

14. Filazzola, A.; Shrestha, N.; MacIvor, S. The contribution of constructed green infrastructure to urban biodiversity: A synthesis and meta-analysis. J. Appl. Ecol. 2019, 56, 2131-2143. [CrossRef]

15. Semeraro, T.; Scarano, A.; Buccolieri, R.; Santino, A.; Aarrevaara, E. Planning of urban green spaces: An ecological perspective on human benefits. Land 2021, 10, 105. [CrossRef]

16. Vasenev, V.; Van Oudenhoven, A.; Romzaykina, O.; Hajiaghaeva, R. The ecological functions and ecosystem services of urban and technogenic soils: From theory to practice (a reiew). Eurasian Soil Sci. 2018, 51, 1119-1132. [CrossRef]

17. O'Riordan, R.; Davies, J.; Stevens, C.; Quinton, J.; Boyko, C. The ecosystem services of urban soils: A review. Geoderma 2021, 395, 115076. [CrossRef]

18. Ignatieva, M.; Haase, D.; Dushkova, D.; Haase, A. Lawns in cities: From a globalized urban green space phemoneno to sustainable nature-based solutions. Land 2020, 9, 73. [CrossRef]

19. Setala, H.; Francini, G.; Allen, J.A.; Jumpponen, A.; Hui, N.; Kotze, D.J. Urban parks provide ecosystem services by retaining metals and nutrients in soils. Environ. Pollut. 2017, 231, 451-461. [CrossRef]

20. Bretzel, F.; Calderisi, M.; Scatena, M.; Pini, R. Soil quality is key for planning and managing urban allotments intended for the sustainable production of homeconsumption vegetables. Environ. Sci. Pollut. Res. 2016, 23, 17753-17760. [CrossRef]

21. Trammell, T.L.E.; Schneid, B.P.; Carreiro, M.M. Forest soils adjacent to urban interstates: Soil physical and chemical properties, heavy metals, disturbance legacies, and relationships with woody vegetation. Urban Ecosyst. 2011, 14, 525-552. [CrossRef]

22. Monserie, M.F.; Watteau, F.; Villemin, G.; Ouvrard, S.; Morel, J.L. Technosol genesis: Identification of organo-mineral associations in a young Technosol derived from coking plant waste materials. J. Soils Sediments 2009, 9, 537-546. [CrossRef]

23. Lorenz, K.; Preston, C.M.; Kandeler, E. Soil organic matter in urban soils: Estimation of elemental carbon by thermal oxidation and characterization of organic matter by solid-state C-13 nuclear magnetic resonance (NMR) spectroscopy. Geoderma 2006, 130, 312-323. [CrossRef]

24. Bouraoui, D.; Cekstere, G.; Osvalde, A.; Vollenweider, P.; Rasmann, S. Deicing salt pollution affects the foliar traits and arthropods' biodiversity of lime trees in riga's street greeneries. Front. Ecol. Evol. 2019, 7, 282. [CrossRef]

25. Zurek, G.; Pogrzeba, M.; Rybka, K.; Prokopiuk, K. Suitability of grass species for phytoremediation of soils polluted with heavy metals. In Breeding Strategies for Sustainable Forage and Turf Grass Improvement; Springer: Dordrecht, The Netherlands, 2013; pp. 245-248.

26. Nagajyoti, P.C.; Lee, K.D.; Sreekanth, T.V.M. Heavy metals, occurrence and toxicity for plants: A review. Environ. Chem. Lett. 2010, 8, 199-216. [CrossRef]

27. Rehman, M.; Liu, L.; Bashir, S.; Saleem, M.H.; Chen, C.; Peng, D.; Siddique, K.H. Influence of rice straw biochar on growth, antioxidant capacity and copper uptake in ramie (Boehmeria nivea L.) grown as forage in aged copper-contaminated soil. Plant Physiol. Biochem. 2019, 138, 121-129. [CrossRef]

28. Saleem, M.H.; Kamran, M.; Zhou, Y.; Parveen, A.; Rehman, M.; Ahmar, S.; Malik, Z.; Mustafa, A.; Anjum, R.M.A.; Wang, B. Appraising growth, oxidative stress and copper phytoextraction potential of flax (Linum usitatissimum L.) grown in soil differentially spiked with copper. J. Environ. Manag. 2020, 257, 109994. [CrossRef]

29. Azimi, R.; Heshmati, G.; Farzam, M.; Goldani, M. Effects of mycorrhiza, zeolite and superabsorbent on growth and primary establishment of agropyron desertorum in mining field (Case Study: Mashhad's Shargh Cement Factory, Iran. J. Rangel. Sci. 2019, 9, 172-183.

30. Wuana, R.A.; Okieimen, F.E. Heavy metals in contaminated soils: A review of sources, chemistry, risks and best available strategies for remediation. Int. Sch. Res. Netw. Ecol. 2011, 2011, 402647. [CrossRef]

31. Jacob, J.M.; Karthik, C.; Saratale, R.G.; Kumar, S.S.; Prabakar, D.; Kadirvelu, K.; Pugazhendhi, A. Biological approaches to tackle heavy metal pollution: A survey of literature. J. Environ. Manag. 2018, 217, 56-70. [CrossRef] 
32. Ahmad, F.; Iqbal, S.; Anwar, S.; Afzal, M.; Islam, E.; Mustifa, T.; Khan, Q.M. Enhanced remediation of chlorpyrifos from soil using ryegrass (Lollium multiflorum) and chlorpyrifos-degrading bacterium Bacillus pumilus C2A1. J. Hazard. Mater. 2012, 237-238, 110-115. [CrossRef]

33. Hussain, F.; Hussain, I.; Ali Khan, A.H.; Muhammad, Y.S.; Iqbal, M.; Soja, G.; Reichenauer, T.G.; Yousaf, Z.S. Combined application of biochar, compost, and bacterial consortia with Italian ryegrass enhanced phytoremediation of petroleum hydrocarbon contaminated soil. Environ. Exp. Bot. 2018, 153, 80-88. [CrossRef]

34. Masu, S.; Popa, M.; Morariu, F.; Lixandru, B.; Popescu, D. Prospects of using leguminous species in phytoremediation of total petroleum hydrocarbons polluted soils. Anim. Sci. Biotechnol. 2014, 47, 1172-1176.

35. Besalatpour, A.A.; Hajabbasi, M.A.; Khoshgoftarmanesh, A.H.; Afyuni, M. Remediation of petroleum contaminated soils around the Tehran oil refinery using phytostimulation method. J. Agric. Nat. Resour. Sci. 2008, 15, $22-37$.

36. Langella, F.; Grawunder, A.; Stark, R.; Weist, A.; Merten, D.; Haferburg, G.; Büchel, G.; Kothe, E. Microbially assisted phytoremediation approaches for two multi-element contaminated sites. Environ. Sci. Pollut. Res. 2014, 21, 6845-6858. [CrossRef] [PubMed]

37. Gołda, S.; Korzeniowska, J. Comparison of phytoremediation potential of three grass, species in soil contaminated with cadmium. Ochr. Srodowiska I Zasobów Nat. 2016, 27, 8-14. [CrossRef]

38. Pandey, V.C.; Bajpai, O. Phytoremediation: From theory toward practice. In Phytomanagement of Polluted Sites; Pandey, V.C., Bauddh, K., Eds.; Elsevier: Amsterdam, The Netherlands, 2019; pp. 1-49.

39. Pandey, V.C.; Singh, D.P. Phytoremediation Potential of Perennial Grasses, 1st ed.; Kindle Edition; Elsevier Inc.: Amsterdam, The Netherlands, 2020; p. 374, ISBN 0128177322.

40. Suman, J.; Uhlik, O.; Viktorova, J.; Macek, T. Phytoextraction of heavy metals: A promising tool for clean-up of polluted environment? Front. Plant Sci. 2018, 9, 1476. [CrossRef]

41. Cempel, M.; Nikel, G. Nickel: A review of its sources and environmental toxicology. Pol. J. Environ. Stud. 2006, 15, 375-382.

42. Fasani, E.; Manara, A.; Martini, F.; Furini, A.; DalCorso, G. The potential of genetic engineering of plants for the remediation of soils contaminated with heavy metals. Plant Cell Environ. 2018, 41, 1201-1232. [CrossRef]

43. Dubchak, S.; Bondar, O. Bioremediation and Phytoremediation: Best Approach for Rehabilitation of Soils for Future Use. In Remediation Measures for Radioactively Contaminated Areas; Gupta, D., Voronina, A., Eds.; Springer: Cham, Switzerland, 2019. [CrossRef]

44. Bernal, M.P.; Alvarenga, P.; Carmody, K.; Pogrzeba, M.; Soja, G. MINIPAPER 3: Biological remediation of contaminated agricultural soils. In EIP-AGRI Focus Group Protecting Agricultural Soils from Contamination; EIP-AGRI: Brussels, Belgium, 2020.

45. Zhang, Y.; Yang, X.; Zhang, S.; Tian, T.; Guo, W.; Wang, J. The influence of humic acids on the accumulation of lead (Pb) and cadmium (Cd) in tobacco leaves grown in different soils. J. Soil Sci. Plant Nutr. 2013, 13, 43.

46. Akinci, I.E.; Akinci, S.; Yilmaz, K. Response of tomato (Solanum lycopersicum L.) to lead toxicity: Growth, element uptake, chlorophyll and water content. Afr. J. Agric. Res. 2010, 5, 416-423.

47. Anderson, T.A.; Guthrie, E.A.; Walton, B.T. Bioremediation in the rhizosphere. Environ. Sci. Technol. 1993, 27, 2630-2636. [CrossRef]

48. Tesar, M.; Reichenauer, T.G.; Sessitsch, A. Bacterial rhizosphere populations of black poplar and herbal plants to be used for phytoremediation of diesel fuel. Soil Biol. Biochem. 2002, 34, 1883-1892. [CrossRef]

49. Pilon-Smits, E. Phytoremediation. Annu. Rev. Plant Biol. 2005, 56, 15-39. [CrossRef]

50. Fan, J.; Zhang, W.; Amombo, E.; Hu, L.; Kjorven, J.; Chen, L. Mechanisms of Environmental Stress Tolerance in Turf grass. Agronomy 2020, 10, 522. [CrossRef]

51. Pastor, J.; Gutierrez-Gines, M.J.; Hernandez, A.J. Heavy-metal phytostabilizing potential of Agrostis castellana Boiss. \& Reuter. Int. J. Phytoremediation 2015, 17, 988-998.

52. Fatima, K.; Imran, A.; Amin, I.; Khan, Q.M.; Afzal, M. Successful phytoremediation of crude-oil contaminated soil at an oil exploration and production company by plants-bacterial synergism. Int. J. Phytoremediation 2018, 20, 675-681. [CrossRef]

53. Mitchell, R.; Lee, D.K.; Casler, M. Switchgrass. In Cellulosic Energy Cropping Systems; Karlen, D.L., Ed.; Wiley: West Sussex, UK, 2014; pp. 75-89.

54. Liebig, M.A.; Schmer, M.R.; Vogel, K.P.; Mitchell, R.B. Soil carbon storage by switch-grass grown for bioenergy. BioEnergy Res. 2008, 1, 215-222. [CrossRef]

55. Taylor, S.H.; Hulme, S.P.; Rees, M.; Ripley, B.S.; Ian Woodward, F.; Osborne, C.P. Ecophysiological traits in C3 and C4 grasses: A phylogenetically controlled screening experiment. New Phytol. 2010, 185, 780-791. [CrossRef]

56. Robbins, M.P.; Evans, G.; Valentine, J.; Donnison, I.S.; Allison, G.G. New opportunities for the exploitation of energy crops by thermochemical conversion in Northern Europe and the UK. Prog. Energy Combust. Sci. 2012, 38, 138-155. [CrossRef]

57. Pandey, V.C. Phytoremediation of heavy metals from fly ash pond by Azolla caroliniana. Ecotoxicol. Environ. Saf. $2012,82,8-12$. [CrossRef]

58. Pandey, V.C.; Pandey, D.N.; Singh, N. Sustainable phytoremediation based on naturally colonizing and economically valuable plants. J. Clean. Prod. 2015, 86, 37-39. [CrossRef]

59. Niknahad, H.; Esfandyari, A.; Rezaei, H. Phytoremediation of cadmium and nickel using Vetiveria zizanioides. Environ. Resourc. Res. 2018, 6, 57-66.

60. Giddens, A. The Consequences of Modernity; Polity Press: Cambridge, UK, 1990. 
61. Stewart, G.H.; Ignatieva, M.E.; Meurk, C.D.; Buckley, H.; Horne, B.; Braddick, T. Urban biotopes of Aotearoa New Zealand (I): Composition and diversity of temperate urban lawns in Christchurch. Urban Ecosyst. 2009, 12, 233-248. [CrossRef]

62. Getter, K.; Rowe, B. The role of extensive green roofs in sustainable development. Hort Sci. 2006, 41, 1276-1285. [CrossRef]

63. Alexandri, E.; Jones, P. Temperature decreases in an urban canyon due to green walls and green roofs in diverse climates. Environ. Build 2008, 43, 480-493. [CrossRef]

64. Burton, E.; Mitchell, L. Inclusive Urban Design: Streets for Life; Oxford Architectural Press: Oxford, UK, $2010 ;$ p. 39.

65. Carmona, M.; Heath, T.; Oc, T.; Tiesdell, T. Public Places Urban Spaces; Taylor \& Francis Ltd: Oxford, UK, 2010.

66. Steiner, F.R.; Thompson, G.F.; Carbonell, A. Nature and Cities: The Ecological Imperative in Urban Design and Planning; Lincoln Institute of Land Policy: Cambridge, UK, 2016.

67. Toomey, D. Designing for the Urban Landscape to Meet 21st Century Challenges; Yale School of the Environment, Yale Environment 360: New Haven, CT, USA, 2018; Available online: http:/ / e360.yale.edu/features/martha_schwartz_urban_landscape_designs_ to_meet_21st_century_challenges (accessed on 20 November 2021).

68. Cabanek, A.; De Baro, M.E.; Newman, P. Biophilic streets: A design framework for creating multiple urban benefits. Sustain. Earth 2020, 3, 7. [CrossRef]

69. Sokolovic, D.; Babic, S.; Radovic, J.; Lugic, Z.; Simic, A.; Zornic, V.; Petrovic, M. Genetic resources of perennial forage grasses in Serbia: Current state, broadening and evaluation. Sel. I Semen. 2017, 23, 69-82. [CrossRef]

70. Pandey, V.C.; Souza-Alonso, P. Market opportunities in sustainable phytoremediation. In Phytomanagement of Polluted Sites; Pandey, V.C., Bauddh, K., Eds.; Elsevier: Amsterdam, The Netherlands, 2019; pp. 51-82.

71. Liu, R.; Jadeja, R.N.; Zhou, Q.; Liu, Z. Treatment and remediation of petroleum-contaminated soils using selective ornamental plants. Environ. Eng. Sci. 2012, 29, 494-501. [CrossRef] [PubMed]

72. Tripathi, V.; Edrisi, S.A.; Abhilash, P.C. Towards the coupling of phytoremediation with bioenergy production. Renew. Sustain. Energy Rev. 2016, 57, 1386-1389. [CrossRef]

73. Albaladejo, M.; Alvarez, R.; Querejeta, J.; Diaz, E.; Castillo, V. Three hydro-seeding revegetation techniques for soil erosion control on anthropic steep slopes. Land Degrad. Dev. 2000, 11, 315-325. [CrossRef]

74. Cao, C.; Chen, L.; Gao, W.; Chen, Y.; Yan, M. Impact of planting grass on terrene roads to avoid soil erosion. Landsc. Urban Plan. 2006, 78, 205-216. [CrossRef]

75. Bochet, E.; Garcia-Fayos, P.; Tormo, J. How can we control erosion of road slopes in semiarid Mediterranean areas Soil improvement and native plant establishment? Land Degrad. Dev. 2010, 21, 110-121. [CrossRef]

76. Thapa, P.; Torralba, M.; Buerkert, A.; Dittrich, C.; Plieninger, T. Ecological and social outcomes of urbanization on regional farming systems: A global synthesis. Ecol. Soc. 2021, 26, Art. 24. [CrossRef]

77. Abaga, N.O.Z.; Dousset, S.; Mbengue, S.; Munier-Lamy, C. Is vetiver grass of interest for the remediation of $\mathrm{Cu}$ and $\mathrm{Cd}$ to protect marketing gardens in Burkina Faso? Chemosphere 2014, 113, 2-47.

78. Spiak, Z.; Gediga, K. Przydatność wybranych gatunków roślin do zasiedlania terenów zdegradowanych przez przemysł miedziowy. Przemyst Chem. 2012, 91, 996-999.

79. Chen, Y.; Shen, Z.; Li, X. The use of vetiver grass (Vetiveria zizanioides) in the phytoremediation of soils contaminated with heavy metals. Appl. Geochem. 2004, 19, 1553-1565. [CrossRef]

80. Aibibu, N.; Liu, Y.; Zeng, G.; Wang, X.; Chen, B.; Song, H.; Xu, L. Cadmium accumulation in Vetiveria zizanioides and its effects on growth, physiological and biochemical characters. Bioresour. Technol. 2010, 101, 6297-6303. [CrossRef]

81. Xu, P.; Wang, Z. Physiological mechanism of hypertolerance of cadmium in Kentucky bluegrass and tall fescue: Chemical forms and tissue distribution. Environ. Exp. Bot. 2013, 96, 35-42. [CrossRef]

82. Zhang, X.; Xia, H.; Li, Z.; Zhuang, P.; Gao, B. Potential of four forage grasses in remediation of Cd and Zn contaminated soil. Bioresour. Technol. 2010, 101, 2063-2066. [CrossRef]

83. Chen, Q.; Wong, J.W.C. Growth of Agropyron elongatum in asimulated nickel contaminated soil with lime stabilization. Sci. Total Environ. 2006, 366, 448-455. [CrossRef]

84. Niu, K.; Zhang, R.; Zhu, R.; Wang, Y.; Zhang, D.; Ma, H. Cadmium stress suppresses the tillering of perennial ryegrass and is associated with the transcriptional regulation of genes controlling axillary bud outgrowth. Ecotox. Environ. Safe. 2021, $212,112002$. [CrossRef]

85. Rabêlo, F.H.S.; Borgo, L. Changes caused by heavy metals in micronutrient content and antioxidant system of forage grasses used for phytoremediation: An overview. Cienc. Rural 2016, 46, 1368-1375. [CrossRef]

86. Rabêlo, F.H.S.; Borgo, L.; Lavres, J. The use of forage grasses for the phytoremediation of heavy metals: Plant tolerance mechanisms, classifications, and new prospects. In Phytoremediation: Methods, Management and Assessment; Matichenkov, V., Ed.; Nova Science Publishers: New York, NY, USA, 2018; pp. 59-103.

87. Niu, Z.; Zhang, X.; Wang, S.; Ci, Z.; Kong, X.; Wang, Z. The linear accumulation of atmospheric mercury by vegetable and grass leaves: Potential biomonitors for atmospheric mercury pollution. Environ. Sci. Pollut. Res. 2013, 20, 6337-6343. [CrossRef]

88. Rabêlo, F.H.S.; Vangronsveld, J.; Baker, A.J.M.; Van der Ent, A.; Alleoni, L.R.F. Are Grasses Really Useful for the Phytoremediation of Potentially Toxic Trace Elements? A Review. Front. Plant Sci. 2021, 12, 778275. [CrossRef] [PubMed]

89. Visconti, D.; Álvarez-Robles, M.J.; Fiorentino, N.; Fagnano, M.; Clemente, R. Use of Brassica juncea and Dactylis glomerata for the phytostabilization of mine soils amended with compost or biochar. Chemosphere 2020, 260, 127661. [CrossRef] 
90. Ishii, Y.; Hamano, K.; Kang, D.-J.; Idota, S.; Nishiwaki, A. Cadmium phytoremediation potential of Napier grass cultivated in Kyushu, Japan. Appl. Environ. Soil Sci. 2015, 2015, 756270. [CrossRef]

91. Awasthi, A.; Singh, K.; Singh, R.P. A concept of diverse perennial cropping systems for integrated bioenergy production and ecological restoration of marginal lands in India. Ecol. Eng. 2017, 105, 58-65. [CrossRef]

92. Jeguirim, M.; Dorge, S.; Trouve, G. Thermogravimetric analysis and emission characteristics of two energy crops in air atmosphere: Arundo donax and Miscanthus giganthus. Bioresour. Technol. 2010, 101, 788-793. [CrossRef]

93. Jacobs, A.; Drouet, T.; Sterckeman, T.; Noret, N. Phytoremediation of urban soils contaminated with trace metals using Noccaea caerulescens: Comparing non-metallicolous populations to the metallicolous 'Ganges' in field trials. Environ Sci Pollut Res Int. 2017, 24, 8176-8188. [CrossRef]

94. Fernando, A.L.; Boleo, S.; Barbosa, B.; Costa, J.; Sidella, S.; Nocentini, A.; Duarte, M.P.; Mendes, B.; Monti, A.; Cosentino, S.L. Perennial grasses: Environmental benefits and constraints of its cultivation in Europe. In Proceedings of the 20-th European Biomass Conference and Exhibition, Milan, Italy, 18-21 June 2012; pp. 18-22.

95. Gupta, P.; Dhawan, S.S.; Lal, R.K. Adaptability and stability based differentiation and selection in aromatic grasses (Cymbopogon species) germplasm. Ind. Crops Prod. 2015, 78, 1-8. [CrossRef]

96. Pruchniewicz, D.; Zolnierz, L.; Andonovski, V. Habitat factors influencing the competitive ability of Calamagrostis epigejos (L.) Roth in mountain plant communities. Turk. J. Bot. 2017, 41, 579-587. [CrossRef]

97. Thomas, C.; Butler, A.; Larson, S.; Medina, V.; Begonia, M. Complexation of lead by Bermuda grass root exudates in aqueous media. Int. J. Phytoremediation 2014, 16, 634-640. [CrossRef]

98. Vasilev, E. Dry mass yield from sainfoin in binary mixtures with ryegrass and cocksfoot. In Sustainable Mediterranean Grasslands and Their Multifunctions; Porqueddu, C., Tavares de Sousa, M.M., Eds.; CIHEAM/FAO/ENMP/SPPF: Zaragoza, Spain, 2008; pp. 241-244.

99. Vasilev, E. Productivity of wheatgrass (Agropyron cristatum (L) Gaertn.) as a component of pasture mixtures for the conditions of the Danube Plain. In Grassland-A European Resource? In Proceedings of the 24th General Meeting of the European Grassland Federation, Lublin, Poland, 3-7 June 2012; pp. 190-193.

100. Subhashini, V.; Swamy, A.V.V.S. Phytoremediation of Pb and Ni contaminated soils using Catharanthus roseus (L.). Univers. J. Environ. Res. Technol. 2013, 3, 465-472.

101. Aftab, K.; Ali, M.D.; Aijaz, P.; Beena, N.; Gulzar, H.J.; Sheikh, K.; Sofia, Q.; Tahir Abbas, S. Determination of different trace and essential element in Lemon grass samples by x-ray fluorescence spectroscopy technique. Int. Food Res. J. 2011, 18, 265-270.

102. Pidlisnyuk, V.; Stefanovska, T.; Lewi, E.E.; Erickson, L.E.; Davis, L.C. Miscanthus as a productive biofuel crop for phytoremediation. Crit. Rev. Plant Sci. 2014, 33, 1-19. [CrossRef]

103. Davidson, C.G.; Gobin, S.M. Evaluation of ornamental grasses for the northern Great Plains. J. Environ. Hortic. 1998, 16, 18-229. [CrossRef]

104. Sharma, R.; Bhardwaj, R.; Gautam, V.; Bali, S.; Kaur, R.; Kaur, P.; Sharma, M.; Kumar, V.; Sharma, A.; Thukral, A.K.; et al. Phytoremediation in waste management: Hyperaccumulation diversity and techniques. In Plants Under Metal and Metalloid Stress; Springer: Singapore, 2018; pp. 277-302.

105. Zorica, T.; Dukic, D.; Katic, S.; Sanja, V.; Mikic, A.; Milic, D.; Lugic, Z.; Jasmina, R.; Sokolovic, D.; Stanisavljevic, R. Genetic resources and improvement of forage plants in Serbia and Montenegro. Acta Agric. Serbica 2005, 10, 3-16.

106. Saha, D.; Kukal, S.S. Soil structural stability and water retention characteristics under different land uses of degraded lower Himalayas of North-West India. Land Degrad. Dev. 2015, 26, 263-271. [CrossRef]

107. Vasileva, V.; Vasilev, E. Utilization efficiency of nitrogen and phosphorus and their response on dry mass accumulation in different forage mixtures. Grassl. Sci. Eur. 2017, 22, 449-453.

108. Chirakkara, R.A.; Reddy, K.R. Plant Species Identification for Phytoremediation of Mixed Contaminated Soils. J. Hazard. Toxic Radioact. Waste 2015, 19, 04015004. [CrossRef]

109. Ghosh, M.; Paul, J.; Jana, A.; De, A.; Mukherjee, A. Use of the grass, Vetiveria zizanioides (L.) Nash for detoxification and phytoremediation of soils contaminated with fly ash from thermal power plants. Ecol. Eng. 2015, 74, 258-265. [CrossRef]

110. Cui, T.; Fang, L.; Wang, M.; Jiang, M.; Shen, G. Intercropping of gramineous pasture ryegrass (Lolium perenne L.) and leguminous forage alfalfa (Medicago sativa L.) increases the resistance of plants to heavy metals. J. Chem. 2018, 11, 7803408. [CrossRef]

111. Suchkova, N.; Darakas, E.; Ganoulis, J. Phytoremediation as a prospective method for rehabilitation of areas contaminated by long term sewage sludge storage: Ukrainian-Greek case study. Ecol. Eng. 2010, 36, 373-378. [CrossRef]

112. Yasin, M.; El-Mehdawi, A.F.; Anwar, A.; Pilon-Smits, E.A.; Faisal, M. Microbial enhanced selenium and iron bio fortification of wheat (Triticum aestivum L.) applications in phytoremediation and bio fortification. Int. J. Phytoremediation 2015, 17, 341-347. [CrossRef]

113. Ziarati, P.; Ziarati, N.N.; Nazeri, S.; Saber-Germi, M. Phytoextraction of heavy metals by two Sorghum spices in treated soil "using black tea residue for cleaning the contaminated soil". Orient. J. Chem. 2015, 31, 317-326. [CrossRef]

114. Kruize, H.; Van der Vliet, N.; Staatsen, B.; Bell, R.; Chiabai, A.; Muiños, G.; Higgins, S.; Quiroga, S.; Martinez-Juarez, P.; Yngwe, M.; et al. Urban green space: Creating a triple win for environmental sustainability, health, and health equity through behavior change. Int. J. Environ. Res. Public Health 2019, 16, 4403. [CrossRef] [PubMed]

115. Ramaiah, M.; Avtar, R. Urban green spaces and their need in cities of rapidly Urbanizing India: A Review. Urban Sci. 2019, 3, 94. [CrossRef] 
116. Katova, A. Study of perennial grass species and varieties for ornamental purposes. J. Mt. Agric. Balk. 2008, 11, 744-757.

117. Ferreira, J.C.; Monteiro, R.; Silva, V.R. Planning a green infrastructure network from theory to practice: The case study of Setúbal, Portugal. Sustainability 2021, 13, 8432. [CrossRef]

118. Antoszewski, P.; Swierk, D.; Krzyzaniak, M. Statistical review of quality parameters of blue-green infrastructure elements important in mitigating the effect of the urban heat island in the temperate climate (c) zone. Int. J. Environ. Res. Public Health 2020, 17, 7093. [CrossRef]

119. Grinberg, N.F.; Lovatt, A.; Hegarty, M.; Lovatt, A.; Skot, K.P.; Kelly, R.; Blackmore, T.; Thorogood, D.; King, R.D.; Armstead, I.; et al. Implementation of genomic prediction in Lolium perenne (L.) breeding populations. Front. Plant Sci. 2016, 7, 133. [CrossRef]

120. Katova, A. Study of Morphological Traits, Biological Properties and Agricultural Value of Plant Germplasm of Perennial Ryegrass (Lolium perenne L.) with a View to Breeding. Ph.D. Thesis, Institute of Forage Crops, Pleven, Bulgaria, $2005 ;$ p. 141.

121. Waterlot, C.; Hechelski, M. Benefits of ryegrass on multicontaminated soils part 1: Effects of fertilizers on bioavailability and accumulation of metals. Sustainability 2019, 11, 5093. [CrossRef]

122. Burges, A.; Alkorta, I.; Epelde, L.; Garbisu, C. From phytoremediation of soil contaminants to phytomanagement of ecosystem services in metal contaminated sites. Int. J. Phytopharm. 2018, 20, 384-397. [CrossRef]

123. Arienzo, M.; Adamo, P.; Cozzolino, V. The potential of Lolium perenne for revegetation of contaminated soil from a metallurgical site. Sci. Total Environ. 2004, 319, 13-25. [CrossRef]

124. Wang, K.; Huang, H.; Zhu, Z.; Li, T.; He, Z.; Yang, X.; Alva, A. Phytoextraction of metals and rhizoremediation of PAHs in co-contaminated (Lolium perenne) or castor (Ricinus communis). Int. J. Phytopharm. 2013, 15, 283-298.

125. Salama, A.K.; Osman, K.A.; Gouda, N.A.R. Remediation of lead and cadmium contaminated soils. Int. J. Phytopharm. 2016, 18, 364-367. [CrossRef]

126. Liu, Y.; Ma, L.Y.; Lu, Y.C.; Jiang, S.S.; Wu, H.J.; Yang, H. Comprehensive analysis of degradation and accumulation of ametryn in soils and in wheat, maize, ryegrass and alfalfa plants. Ecotoxicol. Environ. Saf. 2017, 140, 264-270. [CrossRef]

127. Peng, F.; Li, S.; Xiao-Hui, S.; Ru-Lai, L.; Cheng, J.; Hai-Yan, Z.; Zeng-Jie, L.; Zhi-Min, L.; Wei, G.; Xu-Dong, H.; et al. Response and accumulation ability of perennial ryegrass to plumbum and cadmium stress. Fresenius Environ. Bull. Adv. Food 2017, 26, 598-606

128. Liu, Z.; He, X.; Chen, W.; Zha, M. Eco toxicological responses of three ornamental herb species to cadmium. Environ. Toxicol. Chem. 2013, 32, 1746-1751. [CrossRef]

129. Hechelski, M.; Louvel, B.; Dufrénoy, P.; Ghinet, A.; Waterlot, C. A sustainable approach to manage metal-contaminated soils: A preliminary greenhouse study for the possible production of metal-enriched ryegrass biomass for bio sourced catalysts. Environ. Monit. Assess. 2019, 191, 626. [CrossRef] [PubMed]

130. Li, F.L.; Qiu, Y.; Xu, X.; Yang, F.; Wang, Z.; Feng, J.; Wang, J. EDTA-enhanced phytoremediation of heavy metals from sludge soil by Italian ryegrass (Lolium perenne L.). Ecotoxicol. Environ. Saf. 2020, 91, 110185. [CrossRef]

131. Carvalho, A.; Nabis, C.; Roiloa, S.R.; Rodriguez-Echeverria, S. Revegetation of abandoned copper mines: The role of seed banks and soil amendments. Web Ecol. 2013, 13, 69-77. [CrossRef]

132. Santibanez, C.; Verdugo, C.; Ginocchio, R. Phytostabilization of copper mine tailings with biosolids: Implications for metal uptake and productivity of Lolium perenne. Sci. Total Environ. 2008, 995, 1-10. [CrossRef]

133. Zalewska, M. Response of perennial ryegrass (Lolium perenne L.) to soil contamination with zinc. J. Elem. 2012, 17, 329-343. [CrossRef]

134. Hechelski, M.; Dufrénoy, P.; Louvel, B.; Ghinet, A.; Waterlot, C. An original approach in green chemistry: From assisted phytoremediation of contaminated soil to upcycling of plant biomass for bio sourced catalyst production. In Conference Proceedings, Proceedings of the International Conference, Contaminated Sites, 2018, Banska Bystrica, Slovakia, 8-10 October 2018; European Union: Brussels, Belgium, 2018; pp. 85-88.

135. Jia, Y.; Tang, S.; Wang, R.; Ju, X.; Ding, Y.; Tu, S.; Smith, D.L. Effects of elevated on growth, photosynthesis, elemental composition, antioxidant level, and phytochelatin concentration in Lolium multiforum and Lolium perenne under Cd stress. J. Hazard. Mater. 2010, 180, 384-394. [CrossRef]

136. Mimmo, T.; Bartucca, M.L.; Del Buono, D.; Cesco, S. Italian ryegrass for the phytoremediation of solutions polluted with terbuthylazine. Chemosphere 2015, 119, 31-36. [CrossRef] [PubMed]

137. Xie, H.; Liu, R.; Xu, Y.; Liu, X.; Sun, F.; Ma, Y.; Wang, Y. Effect of In Situ Bioremediation of Soil Contaminated with DDT and DDE by Stenotrophomonas sp. Strain DXZ9 and Ryegrass on Soil Microorganism. Microbiol. Res. 2022, 13, 5. [CrossRef]

138. Jenkin, T.J. Fescue species (Festuca L.). In Handbuch der Planzenzüchtung; 2. Aufl., Band IV; Paul Parey: Berlin/Hamburg, Germany, 1959; pp. 418-434.

139. Bolund, P.; Huhammar, S. Ecosystem services in urban areas. Ecol. Econ. 1999, 29, 293-301. [CrossRef]

140. Tomaškin, J.; Tomaškinová, J.; Kizeková, M. Ornamental grasses as part of public green, their ecosystem services and use in vegetative arrangements in urban environment. Thaiszia-J. Bot. Košice 2015, 25, 1-13.

141. Katova, A.; Baert, J.; Reheul, D. Comparative characteristics of newly developed perennial ryegrass varieties in Bulgaria. In Breeding in a World of Scarcity. Proceedings of the 2015 Meeting of the section of "Fodder Crops and Amenity Grasses" of Eucarpia, Ghent; Roldán-Ruiz, I., Baert, J., Reheul, D., Eds.; Springer International Publishing: Cham, Switzerland, 2016; pp. 35-40. [CrossRef]

142. Jabbari, A.; Rohollahi, I. Establishment and traffic stress response of tall fescue as affected by Mycorrhiza fungi and Trinexapacethyl. Ornam. Hortic. 2019, 25, 461-468. [CrossRef]

143. Strausbaugh, P.D.; Core, E.L. Flora of West Virginia, 2nd ed.; West Virginia University Books: Morgantown, WV, USA, $1977 ;$ p. 1079. 
144. Begonia, M.F.T.; Begonia, G.B.; Ighoavodha, M.; Gilliard, D. Lead accumulation by Tall Fescue (Festuca arundinacea Schreb.) grown on a lead contaminated soil. Int. J. Environ. Res. Public Health 2005, 2, 228-233. [CrossRef]

145. Zurek, G.; Rybka, K.; Pogrzeba, M.; Krzyzak, J.; Prokopiuk, K. Chlorophyll a Fluorescence in Evaluation of the Effect of Heavy Metal Soil Contamination on Perennial Grasses. PLoS ONE 2014, 9, e91475. [CrossRef]

146. Katova, A. Species and varieties of Perennial grasses for high quality forage in Bulgaria. J. Mt. Agric. Balk. 2007, 10, 156-161.

147. Katova, A. New Perennial ryegrass variety (Lolium perenne L.) IFK Harmoniya. J. Mt. Agric. Balk. 2011, 14, 721-739.

148. Katova, A. Tetrany-The first Bulgarian tetraploid Perennial ryegrass variety (Lolium perenne L.). J. Mt. Agric. Balk. 2017, 20, 110-122.

149. Katova, A. Tetramis-New tetraploid Perennial ryegrass variety. J. Mt. Agric. Balk. 2017, 20, 123-134.

150. Katova, A. Svejina-The first Bulgarian Crested wheatgrass variety [Agropyron cristatum (L.) Gaertn.]. J. Mt. Agric. Balk. 2012, 15, 1034-1056.

151. Katova, A. Morava-The first Bulgarian Standard wheatgrass variety [Agropyron desertorum (Fisch.) Schultes]. Banat. J. Biotechnol. 2012, 3, 58-66.

152. Hedblom, M.; Lindberg, F.; Vogel, E.; Wissman, J.; Ahrné, K. Estimating urban lawn cover in space and time: Case studies in three swedish cities. Urban Ecosyst. 2017, 20, 1109-1119. [CrossRef]

153. Egerer, M.; Liere, H.; Lucatero, A. Philpott St. Plant damage in urban agroecosystems varies with local and landscape factors. Ecosphere 2020, 11, e03074. [CrossRef]

154. Onandia, G.; Schittko, C.; Ryo, M.; Bernard-Verdier, M.; Heger, T.; Joshi, J.; Kowarik, I.; Gessler, A. Ecosystem functioning in urban grasslands: The role of biodiversity, plant invasions and urbanization. PLoS ONE 2019, 14, e0225438. [CrossRef]

155. Huang, Q.; Robinson, D.T.; Parker, D.C. Quantifying Spatial-Temporal Change in Land-Cover and Carbon Storage Among Exurban Residential Parcels. Landsc. Ecol. 2014, 29, 275-291. [CrossRef]

156. Lee, J.M.; Thom, E.R.; Wynn, K.; Waugh, D.; Rossi, L.; Chapman, D.F. High perennial ryegrass seeding rates reduce plant size and survival during the first year after sowing: Does this have implications for pasture sward persistence? Grass Forage Sci. 2017, 72 , 382-400. [CrossRef]

157. Anderson, J.R. Effects $f$ Seeding Rates of Perennial Ryegrass (Lolium Perenne L.) On Sediment Loading and Nutrient Transport Via Surface Runoff. Master's Thesis, Louisiana State University, Baton Rouge, LA, USA, 2012; p. 325. Available online: https:/ / digitalcommons.lsu.edu/gradschool_theses/325 (accessed on 31 January 2022).

158. Bertoncini, A.P.; Machon, N.; Pavoine, S.; Muratet, A. Local gardening practices shape urban lawn floristic communities. Landsc. Urban Plan. 2012, 105, 53-61. [CrossRef]

159. Bijoor, N.; Pataki, D.; Haver, D.; Famiglietti, J.A. Comparative study of the water budgets of lawns under three management scenarios. Urban Ecosyst. 2014, 17, 1095-1117. [CrossRef]

160. Heritage Lottery Fund. State of UK Public Parks; Research Report; Heritage Lottery Fund: London, UK, 2014.

161. Carrico, A.R.; Fraser, J.; Bazuin, J.T. Green with Envy: Psychological and social predictors of lawn fertilizer application. Environ. Behav. 2013, 45, 427-454. [CrossRef]

162. Martini, N.F.; Nelson, K.C. The Role of Knowledge in Residential Lawn Management. Urban Ecosyst. 2015, 18, 1031-1047. [CrossRef]

163. Fuentes, T.L. Homeowner preferences drive lawn care practices and species diversity patterns in new lawn floras. J. Urban Ecol. 2021, 7, juab015. [CrossRef]

164. Nielson, L.; Smith, C.L. Influences on residential yard care and water quality: Tualatin watershe. J. Am. Water Resour. Assoc. 2005, 41, 93-106. [CrossRef]

165. Carey, R.; Hochmuth, G.J.; Martinez, C.J.; Boyer, T.H.; Nair, V.D.; Dukes, M.D.; Toor, G.S.; Shober, A.L.; Cisar, J.L.; Trenholm, L.E.; et al. A review of turfgrass fertilizer management practices: Implications for urban water quality. HortTechnology 2012, 22, 280-291. [CrossRef]

166. Brum, O.B.; López, S.; García, R.; André, S.; Calleja, A. Influence of harvest season, cutting frequency and nitrogen fertilization of mountain meadows on yield, floristic composition and protein content of herbage. Rev. Bras. De Zootec. 2009, 38, 596-604. [CrossRef]

167. Bierman, P.M.; Horgan, B.P.; Rosen, C.J.; Hollman, A.B.; Pagliari, P.H. Phosphorus runoff from turfgrass as affected by phosphorus fertilization and clipping management. J. Environ. Qual. 2010, 39, 282-292. [CrossRef]

168. Chen, W.; McCaughey, W.P.; Grant, C.A.; Bailey, L.D. Pasture Type and Fertilization Effects on Soil Chemical Properties and Nutrient Redistribution. Can. J. Soil Sci. 2001, 81, 395-404. [CrossRef]

169. Vasilev, E.; Katova, A.; Dimitrova, T.; Naydenov, Y.; Kuchkova, A.; Stoykova, M.; Chakarov, R.; Kirilov, A. Technology for Creation and Usage of Meadows and Pastures; Agricultural Academy: Sofia, Bulgaria, 2013.

170. Beetz, A.E. A Brief Overview of Nutrient Cycling in Pastures. Appropriate Technology Transfer for Rural Areas (ATTRA). Available online: http:/ / www.attra.ncat.org (accessed on 2 April 2008).

171. Frank, K.W.; O'Reilly, K.M.; Crum, J.R.; Calhoun, R.N. The fate of nitrogen applied to a mature kentucky bluegrass turf. Crop Sci. 2006, 46, 209-215. [CrossRef]

172. Jiao, Y.; Hendershot, Y.H.; Whalen, J.K. Agricultural Practices Influence Dissolved Nutrients Leaching Through Intact Soil Cores. Soil Sci. Soc. Am. J. 2004, 68, 2058-2068. [CrossRef] 
173. Scanlon, B.R.; Jolly, I.; Sophocleous, M.; Zhang, L. Global impacts of conversions from natural to agricultural ecosystems on water resources: Quantity versus quality. Water Resour. Res. 2007, 43, W03437. [CrossRef]

174. Townsend-Small, A.; Czimczik, C.I. Carbon Sequestration and Greenhouse Gas Emissions in Urban Turf. Geophys. Res. Lett. 2010, 37, L02707. [CrossRef]

175. Uddin, M.K.; Juraimi, A.S.; Ismail, M.R.; Brosnan, J.T. Characterizing weed populations in different turfgrass sites throughout the Klang Valley of Western Peninsular Malaysia. Weed Technol. 2010, 24, 173-181. [CrossRef]

176. Slreibig, J.E. Numerical methods illustrating the phytosociology of crops in relation to weed flora. J. Appl. Ecol. 1979 16, 577-587.

177. Qiang, S. Multivariate analysis, description, and ecological interpretation of weed vegetation in the summer crop fields of Anhui province, China. J. Integr. Plant Biol. Former. Acta Bot. Sin. 2005, 47, 1193-1210. [CrossRef]

178. Zhang, J.; Liu, Y.; Yu, J.; Zhang, W.; Xie, Y.; Ge, N. Key Factors Influencing Weed Infestation of Cool-season Turfgrass Festuca arundinacea Schreb. Areas during Early Spring in the Tianjin Region, China. Hortscience 2018, 53, 723-728. [CrossRef]

179. Andreeva-Fetvadzhieva, N. Weed Control, 3rd ed.; Todor Dimitrov Printing House: Sofia, Bulgaria, $1973 ;$ p. 357.

180. Bogdanov, V.L.; Posternak, T.S.; Pasko, O.A.; Kovyazin, V.F. The issues of weed infestation with environmentally hazardous plants and methods of their control. IOP Conf. Series: Earth Environ. Sci. 2016, 43, 012036. [CrossRef]

181. Peerzada, A.M.; Ali, H.H.; Hanif, Z.; Bajwa, A.A.; Kebaso, L.; Frimpong, D.; Iqbal, N.; Namubiru, H.; Hashim, S.; Rasool, G.; et al. Eco-biology, impact, and management of Sorghum halepense (L.) Pers. Biol. Invasions 2017, 19, 1-19. [CrossRef]

182. Harlan, J. Cynodon species and their value for grazing and hay. Herb. Abstr. 1970, 40, 233-238.

183. Sheley, R. Revegetating russian knapweed (Acroptilon repens) and green rabbitbrush (Ericameria teretifolia) infested rangeland in a single entry. Weed Sci. 2007, 55, 365-370. [CrossRef]

184. Cameron, R.W.F.; Blanusa, T.; Taylor, J.E.; Salisbury, A.; Halstead, A.J.; Henricot, B. The domestic garden-Its contribution to urban green infrastructure. Urban For. Urban Green. 2012, 11, 129-137. [CrossRef]

185. Ignatieva, M.; Ahrné, K.; Wissman, J.; Eriksson, T.; Tidåker, P.; Hedblom, M.; Kätterer, T.; Marstorp, H.; Berg, P.; Eriksson, T.; et al. Lawn as a cultural and ecological phenomenon: A conceptual framework for transdisciplinary research. Urban For. Urban Green. 2015, 14, 383-387. [CrossRef]

186. Marinov-Serafimov, P.; Golubinova, I.; Vasileva, V. Dynamics and distribution of weed species in weed associations. Indian J. Agric. Sci. 2019, 89, 105-110.

187. Dimitrova, T. Study of Weeds and Their Control in Seed Production of Perennial Legumes and Cereal Grasses in Individual and Mixed Crops. Ph.D. Thesis, Agricultural Academy Sofia, Institute of Forage Crops Pleven, Pleven, Bulgaria, $1984 ;$ p. 168.

188. Damyanova, N. Studies on the Use of Perennial Grass Mixture. Ph.D. Thesis, Agricultural Academy Sofia, Institute of Forage Crops Pleven, Pleven, Bulgaria, 1989; p. 152

189. Katova, A.; Dimitrova, T. Selectivity of some herbicides to standard wheatgrass (Agropyron desertorum (Fisch.) Schultes) during stand establishment and seed production. Pestic. Phytomed. 2013, 28, 125-131. [CrossRef]

190. Marinov-Serafimov, P.; Golubinova, I. The infl uence of some herbicides on seed production in standard wheatgrass (Agropyron desertorum (Fisch.) Schultes). Bulg. J. Agric. Sci. 2019, 25, 1191-1197.

191. Majidi, M.R.; Mirshekari, B.; Samedani, B.; Farahvash, F.; Hajnajari, H. Effect of four pre-planted cover crop species on weed control and population dynamics. Italian J. Agron. 2020, 15, 253-260. [CrossRef]

192. Duke, S. Natural pesticides from plants. In Advances in New Crops; Janick, J., Simon, J.E., Eds.; Timber Press: Portland, OR, USA, 1990; pp. 511-517.

193. Tworkoski, T. Herbicide effects of essential oils. Weed Sci. 2002, 50, 425-431. [CrossRef]

194. Monteiro, A.; Santos, S. Sustainable approach to weed management: The role of precision weed management. Agronomy 2022, 12, 118. [CrossRef]

195. Radicetti, E.; Mancinelli, R. Sustainable weed control in the agro-ecosystems. Sustainability 2021, 13, 8639. [CrossRef]

196. Carriger, J.F.; Rand, G.M.; Gardinali, P.R.; Perry, W.B.; Tompkins, M.S.; Fernandez, A.M. Pesticides of potential ecological concern in sediment from south florida canals: An ecological risk prioritization for aquatic arthropods. Soil Sediment Contam. 2006, 15, 21-45. [CrossRef]

197. Mostafalou, S.; Abdollahi, M. Concerns of environmental persistence of pesticides and human chronic diseases. Clin. Exp. Pharmacol. 2012, S5, e002. [CrossRef]

198. White, P. Weed Management. In Proceedings of the a General Meeting of Electors of the Town of Bassendean, Bassendean, Australia, 9 February 2022.

199. Ayeni, A.O.; Majek, B.A.; Johnson, J.R.; Obal, R.G. Container nursery weed control: Bitter cress, groundsel, and oxalis. Rutgers Coop. Ext. Fact Sheet 1999, FS939.

200. Newman, J.P. Container Nursery Production and Business Management Manual; University of California (System), Division of Agriculture and Natural Resources: Berkeley, CA, USA, 2014; p. 345, ISBN 9781601078421.

201. Coleman, R.; Penner, D. Organic acid enhancement of pelargonic acid. Weed Technol. 2008, 22, 38-41. [CrossRef]

202. Arboleya, J.E.; Masabni, J.G.; Particka, M.G.; Zandstra, B.H. Identification of pre-harvest desiccants for use in onion production. Hort Technol. 2005, 15, 808-811. [CrossRef]

203. Barker, A.; Prostak, R. Management of vegetation by alternative practices in fields and roadsides. Int. J. Agron. 2014, 2014 , 207828. [CrossRef] 
204. Muñoz, M.; Torres-Pagán, N.; Peiró, R.; Guijarro, R.; Sánchez-Moreiras, A.M.; Verdeguer, M. Phytotoxic effects of three natural compounds: Pelargonic acid, carvacrol, and cinnamic aldehyde, against problematic weeds in Mediterranean crops. Agronomy 2020, 10, 791. [CrossRef]

205. Travlos, I.; Rapti, E.; Gazoulis, I.; Kanatas, P.; Tataridas, A.; Kakabouki, I.; Papastylianou, P. The herbicidal potential of different pelargonic acid products and essential oils against several important weed species. Agronomy 2020, 10, 1687. [CrossRef]

206. Pavela, R.; Benelli, G. Essential oils as ecofriendly biopesticides? Challenges and constraints. Trends Plant Sci. 2016, 21, 1000-1007. [CrossRef]

207. Bakkali, F.; Averbeck, S.; Averbeck, D.; Idaomar, M. Biological effects of essential oils-A review. Food Chem. Toxicol. 2008, 46, 446-475. [CrossRef] [PubMed]

208. European Food Safety Authority. Conclusion on the peer review of the pesticide risk assessment of the active substance Fatty acids C7 to C18 (approved under Regulation (EC) No 1107/2009 as Fatty acids C7 to C20). EFSA J. 2013, 11, 3023. [CrossRef]

209. Ivany, J. Acetic acid for weed control in potato (Solanum tuberosum L.). Can. J. Plant Sci. 2010, 90, 523-542. [CrossRef]

210. Wilen, C.; Perez, G. Natural Herbicides: Are They Effective? UC Weed Science. Weed Control, Management, Ecology, and Minutia. 2012. Available online: https://ucanr.edu/blogs/blogcore/postdetail.cfm?postnum=6498 (accessed on 3 February 2022).

211. Li, J.; Zhang, Q.; Hu, W.; Yang, X.; He, H. Stability of phenolic acids and the effect on weed control activity. J. Korean Soc. Appl. Biol. Chem. 2015, 58, 919-926. [CrossRef] 